\title{
Management of Musculoskeletal Pain: An Update with Emphasis on Chronic Musculoskeletal Pain
}

\author{
Salah N. El-Tallawy (D) · Rohit Nalamasu • Gehan I. Salem • \\ Jo Ann K. LeQuang · Joseph V. Pergolizzi · Paul J. Christo
}

Received: September 2, 2020 / Accepted: January 9, 2021 / Published online: February 11, 2021

(C) The Author(s) 2021

\begin{abstract}
Musculoskeletal pain is a challenging condition for both patients and physicians. Many adults have experienced one or more episodes of musculoskeletal pain at some time of their lives, regardless of age, gender, or economic status. It affects approximately $47 \%$ of the general population. Of those, about $39-45 \%$ have longlasting problems that require medical consultation. Inadequately managed musculoskeletal
\end{abstract}

S. N. El-Tallawy $(\square)$

Anesthesia and Pain Management Department, King Khalid University Hospital, College of Medicine,

King Saud University, Riyadh, Saudi Arabia

e-mail: salaheltallawy@yahoo.com

S. N. El-Tallawy

Faculty of Medicine, Minia University and NCI,

Cairo University, Cairo, Egypt

R. Nalamasu

Department of Physical Medicine and

Rehabilitation, University of Nebraska Medical

Center, Omaha, NE, USA

G. I. Salem

Rheumatology, Rehabilitation and Physical

Medicine Department, Assiut University Hospital,

Assiut, Egypt

G. I. Salem

Rehabilitation Medicine Department, King Khalid University Hospital, King Saud University, Riyadh, Saudi Arabia pain can adversely affect quality of life and impose significant socioeconomic problems. This manuscript presents a comprehensive review of the management of chronic musculoskeletal pain. It briefly explores the background, classifications, patient assessments, and different tools for management according to the recently available evidence. Multimodal analgesia and multidisciplinary approaches are fundamental elements of effective management of musculoskeletal pain. Both pharmacological, non-pharmacological, as well as interventional

J. A. K. LeQuang · J. V. Pergolizzi

NEMA Research, Inc., Naples, FL, USA

P. J. Christo

Division of Pain Medicine, Department of

Anesthesiology and Critical Care Medicine, Johns

Hopkins University School of Medicine, Baltimore, MD, USA 
pain therapy are important to enhance patient's recovery, well-being, and improve quality of life. Accordingly, recent guidelines recommend the implementation of preventative strategies and physical tools first to minimize the use of medications. In patients who have had an inadequate response to pharmacotherapy, the proper use of interventional pain therapy and the other alternative techniques are vital for safe and effective management of chronic pain patients.

Keywords: Alternative treatment; Assessment of musculoskeletal pain; Chronic musculoskeletal pain; Interventional pain techniques; Musculoskeletal pain; NSAID; Opioids; Pharmacotherapy

\section{Key Summary Points}

Musculoskeletal pain is prevalent and can develop into chronic pain syndromes that can be challenging to manage.

Chronic musculoskeletal pain may have a neuropathic component, which may necessitate multimodal and multidisciplinary intervention.

Patient's education, preventative strategies, and non-pharmacological pain control techniques are preferable to minimize the use of pharmacological therapy but conservative pain control methods are not always effective for patients with moderate-to-severe chronic pain.

A variety of pharmacological approaches are available and should be individualized to meet the patient's needs.

In cases where conventional pharmacotherapy is inadequate, interventional strategies may be needed to restore patient's functional level, and reduce pain.

\section{DIGITAL FEATURES}

This article is published with digital features, including a summary slide, to facilitate understanding of the article. To view digital features for this article go to https://doi.org/10.6084/ m9.figshare.13547138.

\section{INTRODUCTION}

Chronic musculoskeletal pain (in particular, low back pain) is the main contributor to disability worldwide [1]. According to the World Health Organization (WHO), $20-33 \%$ of the world's population has some form of chronic musculoskeletal pain, translating to 1.75 billion people globally [2]. Musculoskeletal pain is defined as acute or chronic pain that affects bones, muscles, ligaments, tendons, and even nerves, and the pain associated with musculoskeletal (MSK) disorders is a common medical and socioeconomic problem worldwide [3]. It comprises a number of different pain syndromes, which range from local pain to neuropathic pain [2]. Chronic MSK pain increases suffering in daily activities, drug consumption, and high frequency of sick leave and disability pensions, and results in significantly diminished quality of life. It also poses a major public health problem, creating substantial costs for healthcare systems and disability insurance [4].

Musculoskeletal pain is primarily somatic in nature, but the presence of musculoskeletal pain does not preclude the addition of other pain syndromes, including neuropathic and/or visceral pain syndromes. The most prevalent forms of musculoskeletal pain are chronic low back pain, neck pain, and the pain associated with osteoarthritis and rheumatoid arthritis, but musculoskeletal pain also includes sprained muscles, pain associated with fracture, shoulder pain, and others. Advancing age increases the risk of musculoskeletal pain, although it may occur at any age. Virtually everyone has some form of musculoskeletal pain over the course of a lifetime. Many people report persistent symptoms or recurrent clinical symptoms, which accentuates the physical, psychological, and socio-economic impact of MSK pain $[2,5]$. 
Musculoskeletal pain is mainly treated by general or family practitioners, physiatrists, or orthopedic specialists, but clinicians in all fields may treat patients who present with some form of musculoskeletal pain. Comprehensive care of MSK pain occurs through a thorough initial evaluation, including assessment of both the medical and the probable bio-psychosocial factors contributing to a painful condition in order to develop a treatment plan. Therefore, a multidisciplinary and holistic approach to manage MSK pain by utilizing more than one treatment modality is appropriate, and can result in improved outcomes [6].

\section{OBJECTIVES}

In light of the available data related to the impact of chronic musculoskeletal pain on the patients, the main objectives of this review are:

- To concentrate available resources and highlight the gaps to help patients with the most effective treatment.

- To identify patient groups with persistent pain and the most vulnerable groups.

- To understand the different treatment options and provide the appropriate management of MSK pain, with special focus on the interventional pain therapy, according to the best available evidence and to minimize adverse outcomes.

- To enhance physical recovery, psychological well-being, and improve quality of life.

\section{METHODS}

An extensive computer search of the current literature in the PubMed, MEDLINE, and Embase databases was performed using the following keywords: "musculoskeletal pain", "pharmacotherapy of musculoskeletal pain", "alternative and physical therapy", or "interventional pain procedures for musculoskeletal pain". Articles that were relevant and presented information on the management of musculoskeletal pain were included. Manual screening of references was conducted, and additional references were added. The authors take complete responsibility for the integrity and accuracy of the data. In compliance with ethics guidelines, this article is based on previously conducted studies and does not contain any studies with human participants or animals performed by any of the authors.

\section{EPIDEMIOLOGY}

Chronic pain is prevalent in the Western world, where approximately $18 \%$ of the European population is currently affected by moderate-tosevere chronic pain and about $25 \%$ of the United States population $[2,8]$. Most adults have experienced one or more brief episodes of musculoskeletal pain associated with injury or overuse. This affects between 13.5 and $47 \%$ of the general population [7].

The prevalence of certain types of musculoskeletal pain showed wide variations; for example, low back pain (LBP) is extremely common, affecting $30-40 \%$ of adults, while other rheumatologic problems with musculoskeletal pain components like fibromyalgia and rheumatoid arthritis are fairly low, affecting only $2 \%$ [9]. The prevalence of neck and shoulder pain ranges from 15 to $20 \%$, and 10 to $15 \%$ for knee pain [10].

The patterns of musculoskeletal pain problems vary greatly by age and sex, e.g., knee pain from osteoarthritis is extremely common in the elderly, affecting over one-third of people over age 60 , while the prevalence of pain is about 1.5-2 times more common in women than in men, and the ratio is over four females to one male for fibromyalgia [10].

Older people are more likely than younger people to have chronic musculoskeletal pain, although the subject of chronic musculoskeletal pain in the pediatric population has not been well studied. Age is an important risk factor to consider; osteoarthritis (the most common form of arthritis) afflicts $43 \%$ of people $\geq 65$ years of age [11]. With old age, joints deteriorate, muscles weaken, and lifestyles tend to become more sedentary, all of which may contribute to musculoskeletal pain. However, it is important for clinicians to bear in mind that 
musculoskeletal pain can occur in patients at any age, including small children and adolescents.

Smoking has been identified as a risk factor for musculoskeletal pain. Other risk factors include: lower educational status, sedentary lifestyle, poor or limited social interactions, low income, insomnia or sleep disorders, anxiety, depression, and manual labor [3]. Fewer expected risk factors have been identified as: recent immigration, being non-Caucasian, and being separated, widowed, or divorced [12]. The racial distinctions may not be universal or reproducible across multiple studies; for example, $78 \%$ of Americans with osteoarthritis are nonHispanic Caucasians even though risk factors for musculoskeletal pain suggest non-Caucasians are at higher risk [11].

While some studies of chronic widespread musculoskeletal pain have suggested that there are no differences between urban and rural populations [13], global prevalence of pain conditions, especially in areas like Central America, South America, and Sub-Saharan Africa, is hard to truly estimate due to poor epidemiologic data. This leads to a likely underestimation of the global impact of musculoskeletal pain. However, data indicate that the global burden of hip and knee osteoarthritis as well as musculoskeletal pain is generally higher in the more industrialized countries including the United States and Europe [14]. Geographical variation in musculoskeletal pain management treatment has been studied across the world, finding varying use of diagnostic imaging based on rural or urban locations [15]. Globally, less-affluent areas have been shown to have more musculoskeletal pain issues compared to more affluent areas [16].

\section{DEFINITIONS}

The International Association for the Study of Pain (IASP) has updated the definition of pain as "An unpleasant sensory and emotional experience associated with or resembling that associated with, actual or potential tissue damage" [17].
The Pain Task Force of the (IASP), defines Chronic Primary Musculoskeletal Pain (CPMP) as "chronic pain in the muscles, bones, joints, or tendons that is characterized by significant emotional distress (i.e., anxiety, anger, frustration, and depressed mood) or functional disability" $[17,18]$.

Musculoskeletal disorders (MSDs) are injuries or pain in the human musculoskeletal system, including the joints, ligaments, muscles, nerves, tendons, and structures that support limbs, neck, and back. MSDs can arise from a sudden exertion (e.g., lifting a heavy object), or they can arise from making the same motions repeatedly repetitive strain, or from repeated exposure to force, vibration, or awkward posture [2].

\section{SUMMARY OF COMMON PROBLEMS IN MUSCULOSKELETAL PAIN}

The authors have summarized the common problems associated with musculoskeletal pain care as the following [19]:

- Overuse of imaging:

Around $69 \%$ of general practitioners refer patients for radiography at first presentation and $82 \%$ would refer for ultrasound evaluation. Between 25 and $42 \%$ of patients with LBP undergo imaging even though its routine use is discouraged. Findings demonstrate a poor relationship between imaging and symptoms, and making a recommendation for imaging in the absence of red flags is not recommended unless: (1) serious pathology is suspected, (2) there has been an unsatisfactory response to conservative care or unexplained progression of signs and symptoms, or (3) imaging is likely to change management [19-21].

- Overuse of opioids:

The efficacy of opioids for musculoskeletal pain management is questionable for both chronic and acute pain conditions. The early use of opioids has been associated with poorer outcomes in LBP [19]. Also, it is suggested that the use of opioids should be cautiously limited and restricted to a short 
duration for the treatment of LBP [22]. Although limiting the use of opioids is recommended, there is increasing use and an 'epidemic' of prescription opioid-related harms [23]. Data from the "American Society of Interventional Pain Physician" showed a continuous increase in illicit opioid abuse, and adverse consequences, including death [24]. More recent data indicate that prescription opioid mortality has been overestimated, and the US Department of Health has indicated that at least $60 \%$ of opioid overdose is due to illicit drugs. Of the illicit opioids including fentanyl and heroin, synthetic fentanyl has seen a significant rise of involvement in overdose deaths. Along with this, evidence also points to a polypharmacy overdose crisis; 50\% of opioid-positive toxicology deaths include other illicit substances, with an average of six found on toxicology reports on mortality. These data may indicate that the opioid overdose epidemic may be partially due to other confounding factors rather than purely prescription drugs [25].

- Overuse of surgery:

The rate of knee arthroscopy for knee osteoarthritis has increased in the general US population from 3 to $4 \%$ [26]. The rates of shoulder subacromial decompression and rotator cuff repair [27] have increased markedly, even though surgical outcomes are comparable with exercise-based rehabilitation or sham surgery [28].

- Failure to provide education:

Only about $20 \%$ of patients with LBP are given advice and education in a primary care setting [19]. This alarmingly low percentage is reflected in the quality of care for the management of MSK pain. As with many medical issues, strong patient education of musculoskeletal disorders and pain syndromes are important in improving care [29].

- Misclassification:

Some pain conditions like chronic widespread pain, whiplash, and fibromyalgia are challenging conditions related to soft tissue pain that are sometimes considered musculoskeletal pain; however, some believe that it may be more helpful in terms of treatment options to consider them as separate conditions [30]. Delineating between interconnected rheumatologic, musculoskeletal, and psychiatric disorders is a challenging endeavor, and while these conditions definitely affect musculature, it is not clear if adding them to musculoskeletal pain is helpful in terms of discussing disease mechanisms and treatments.

These conditions can be classified as nociplastic pain, a new pain classification from the IASP. Somatic nociceptive pain also encompasses syndromes like fibromyalgia and complex regional pain syndrome [17], and practitioners unfamiliar with the new classification may unknowingly place these syndromes under musculoskeletal pain.

\section{Musculoskeletal Pain Symptomology}

The most common presenting symptom of musculoskeletal disorders is pain. The pain associated with musculoskeletal disorders is sometimes severe, with about a quarter of adult patients reporting pain at levels of $\geq 7$ on a $0-10$ numeric analog pain scale [11]. Musculoskeletal pain tends to be intense and localized. For pain in the joints, certain postures or movements may worsen or relieve the pain. Some people with moderate musculoskeletal pain describe the pain as similar to the feeling of an overworked or strained muscle. Regional pain of a single joint is a common presentation [31].

Body aches, malaise, and stiffness are all common in musculoskeletal pain patients. For many individuals, joint stiffness and aches are worst upon arising or after a period of inactivity but joints may "loosen up" as the individual starts to move around. Exercise can improve range of motion, mobility, and reduce pain, but patients who exercise must be careful not to overuse or injure muscles and joints [30].

Fatigue and sleep disorders are common in people with musculoskeletal pain and may be interrelated. Musculoskeletal pain can interfere with sleep or cause a person to wake in the night. Some patients with musculoskeletal pain may indicate that they cannot find a comfortable position for sleep at all and may try to sleep in recliners or sitting up. This reduces the 
quality and quantity of restorative sleep which, along with the chronic pain, can cause the patient to experience profound fatigue that can limit function [31].

A subset of patients with musculoskeletal pain may experience muscle aches, muscle "twitching," or other uncomfortable sensations of the muscles. Chronic musculoskeletal disorders may have a neuropathic component, the pain of which is often accompanied by sensations of burning, shocks, or "electrical" pain. Neuropathic pain can have an abrupt onset and often occurs without warning. Neuropathic pain may also manifest as numbness or "pins and needles". It must be noted that the experience of musculoskeletal symptoms varies widely among patients [31]. Furthermore, the severity of symptoms or pain intensity may not necessarily correlate with the severity of the musculoskeletal injury.

\section{CLASSIFICATIONS OF PAIN}

Musculoskeletal pain represents a diagnostic and therapeutic problem. There is growing evidence that muscle hyperalgesia, referred pain, and widespread hyperalgesia play an important role in chronic musculoskeletal pain. In addition to the sensory consequences of musculoskeletal pain, the motor control systems are also affected, and the related biomechanics [32].

According to the pathophysiological categories, pain can be classified into nociceptive, neuropathic, nociplastic, idiopathic, or mixed type [32]. ICD (International Classification of Diseases)-11 added chronic pain a separate "parent code" with multiple subcodes, of which one is chronic secondary musculoskeletal pain. Due to the significant overlap, ICD-11 allows for subdiagnoses to full under the realm of multiple parent codes, meaning that a musculoskeletal chronic pain diagnosis may fall under the chronic pain parent code as well as under one of the pathophysiological categories stated above [33]. An understanding of pain classifications is important when discussing musculoskeletal syndrome pain due to its variable presentation.

Nociceptive pain is the most common type of pain following tissue injury and the primarily category of pain implicated in musculoskeletal pain. Nociceptive pain is also known as physiological or inflammatory pain, and has a protective function [34, 35]. Patients describe nociceptive pain as sharp, throbbing, or aching and it is usually well localized. Nociceptive pain is a normal sensory experience resulting from the excitation of peripheral pain receptors, which activates the appropriate spinal cord pathways and their sensory nuclei $[29,36]$.

Types of nociceptive pain include somatic pain, bony pain, and visceral pain. Somatic pain originates from superficial tissues such as the skin, subcutaneous tissues, and muscles due to soft tissue inflammation or trauma. It may be intermittent to constant pain, characterized by sharp, knife-like, and it is with localized pain (the patient is able to point to exactly where the pain is) $[32,35,36]$. Bone pain originates from the body skeleton due to bone fractures and trauma. It is localized, sharp pain, and noted to be deep, depending on the site of origin. It is associated with tenderness of the overlying soft tissue covering $[32,36]$. Visceral pain originates from deep visceral organs, e.g., appendicitis, renal or biliary colic. Visceral pain is characterized by dull aching pain, colicky, or cramping in nature. It is poorly localized, usually referred to distal structures, and is associated with nausea/ vomiting [32, 35, 36].

Other major types of pain include neuropathic pain caused by a primary lesion or dysfunction of the somatosensory nervous system, also known as pathological pain, but it does not have a protective function. Neuropathic pain usually occurs along the distribution of the involved neural tissue or structure and is commonly associated with sensory changes such as hypoesthesia/hyperesthesia, hypoalgesia/hyperalgesia, allodynia, or paresthesia. Patients describe neuropathic pain as burning, shooting, electric-like, numbness, pins or needles [37, 38].

Mixed pain occurs when a component of continued nociceptive pain coexists with a component of neuropathic pain in the same patient. Patients with persistent back and leg pain following lumbar spine surgery (failed back surgery syndrome or FBSS) represent a common example. The mechanical low back pain represents the nociceptive component, while the 
radicular lower-limb pain represents a neurological component [36, 37].

Idiopathic pain is when pain is disproportionate with the type or degree of tissue injury or there is no definite cause to explain the pain. Psychological factors may be involved with this type of pain $[36,37]$.

A new classification of nociplastic pain has recently been defined by the IASP as "pain that arises from altered nociception despite no clear evidence of actual or threatened tissue damage causing the activation of peripheral nociceptors or evidence for disease or lesion of the somatosensory system causing the pain" [39]. Nociceptive pain may overlap with the neuropathic pain due to the limited methods of assessments or evaluation.

\section{PATIENT EVALUATION}

Many forms of musculoskeletal pain are relatively straightforward to diagnose. Clinicians rely on patient symptoms and reports, patient history, physical examination, and, in some cases, radiology. The most frequently reported symptoms of musculoskeletal pain are pain, usually localized to a specific area, fatigue, and sleep disruptions often caused by pain. In many cases, the patient can identify the injury that caused the pain.

The patient's history should include general medical history, history of the current illness, and additional history of the associated comorbidity, and past history of previous similar attacks, and the performance of any diagnostic tests. The evaluation should include information's regarding previous or current therapy including the use of controlled medication, drug abuse and its effects. The physical examination should include a general examination, as well as neurological and musculoskeletal examinations such as sensory, motor, autonomic changes, and deformity [40, 41].

The bio-psychosocial assessment should include the changes in the occupational status and the impact of the previous treatments on a patient's ability to perform routine activities. This will help in the identification of patients with severe or persistent pain and the more vulnerable groups such as the elderly and disabled $[40,41]$.

\section{Pain Assessments}

A strong history, identifying pain type, severity, functional impact, and context should be conducted in all patients with pain. This will help the identification of patients with persistent pain and help in the selection of treatment options that are most likely to be effective $[29,36]$. Since MSK pain can be intractable, improving pain-related disability appears to be a more meaningful goal than pain control for some patients, so the use of disability-related metrics of quality-of-life assessments may be particularly relevant [42].

Any pain assessment tool should include the type of pain, severity, functional impact, and context. This helps guide the provider and patient to treatment options that are most likely to be effective [40]. However, there is a strong recommendation by many international guidelines for using more comprehensive pain scores like the McGill pain questionnaire [43, 44].

Generally, pain assessment tools can be classified into uni-dimensional or multi-dimensional scores [36].

- Uni-dimensional scores measure the pain intensity only, and are usually used for assessment of acute pain, e.g., visual analog scale (VAS), numerical rating scale (NRS), verbal rating scale (VRS), and facial expression for pediatric patients [29] (Fig. 1).

- Multi-dimensional scores measure the pain scores as well as the associated symptoms such as sleep disturbance, mood, appetite, behavior, and other related activities. Multi-dimensional scores are used for the assessment of chronic pain, e.g., McGill Pain Questionnaire, and Pain Inventory Scale [29].

- Neuropathic pain diagnostic scales include a set of pain symptoms, clinical examination, or labs. Leeds Assessment of Neuropathic Symptoms and Signs (LANSS) has five symptom items and two clinical assessment items. Douleur Neuropathique EN 4 questions (DN4) has ten items: seven symptomatic and three from clinical examination. Pain 


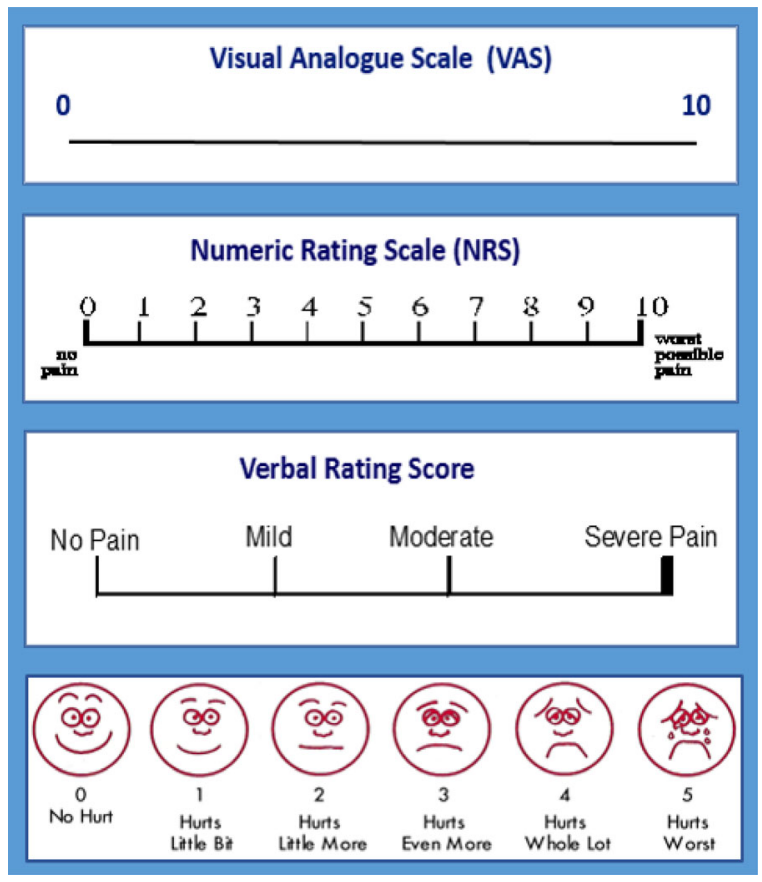

Fig. 1 Pain assessment tools

DETECT has nine self-reported items that do not require a clinical examination [45].

\section{TREATMENT OF MUSCULOSKELETAL PAIN}

A combination of pharmacological and nonpharmacological interventions are important, and they may be used together to manage a patient's pain. For patients with chronic MSK pain, clinicians and patients should initially select non-pharmacologic treatment, including home exercises and multidisciplinary rehabilitation protocols. In patients with chronic MSK pain who have had an inadequate response to non-pharmacologic therapy, pharmacologic treatment with NSAIDs should be considered as first-line therapy with or without adjuvant therapy [46].

\section{General Recommendations}

for Musculoskeletal Pain Management $[19,41]$

1. Patient's education about their condition, self-help resources, and management options and use shared decision-making processes. This includes appropriate advice about nonpharmacological treatment strategies, such as physical activity, rest, exercise, and so on.

2. Comprehensive patient assessments including detailed history taking with the assessment of physical and psychosocial factors. Physical examination including full neurological assessment, but radiological imaging is discouraged unless indicated.

3. Multimodal and multidisciplinary interventions should be part of a treatment strategy for patients with chronic MSK pain.

4. Facilitate early recovery or rapid resumption of work with continuous evaluation of the patient's progress including the use of outcome measures.

5. If other modalities are ineffective, consider the prescription of opioids by comprehensive assessments and screening for opioid abuse, the effectiveness of long-term opioid therapy, monitoring for adherence and side effects, and discontinue opioids because of lack of response, adverse effects, and abuse [24].

\section{Multidisciplinary and Multimodal Approaches}

A multimodal approach to pain management consists of using treatments from one or more clinical disciplines incorporated into an overall treatment plan $[47,48]$. There is strong evidence that the concurrent use of multiple medications that work by different mechanisms of action and at different sites are associated with better analgesia with fewer side effects. This is the premise of multimodal analgesia $[43,44]$.

A multidisciplinary approach address different aspects of chronic pain conditions including biopsychosocial effects of the medical condition on the patient $[47,48]$. Multidisciplinary pain services offer a variety of coherent treatment approaches that recognize that pain is a multifaceted problem requiring a multifaceted approach and continuity of care [49]. The core group for the multidisciplinary treatment service may include a pain medicine physician, a physiatrist, a neurologist, a physical and or 
occupational therapist, and a psychiatrist or clinical psychologist, according to local needs, resources, and available expertise [50]. In addition, to complete clinical evaluation, psychological evaluation, functional capabilities, disability scores, behavioral responses to pain, and all previous medical records are needed to avoid repeating appropriately performed studies and unsuccessful treatment approaches [51].

\section{(I) Pharmacological}

Pharmacological treatment is the mainstay for the management of pain. A wide range of analgesics have been used in the treatment of MSK pain (Table 1). In 1986, the World Health Organization (WHO) published the pain ladder system. Since then, the ladder has guided clinicians all over the world in treating pain [52]. The basic principles of achieving analgesia according to the WHO ladder focus on the main key principles that ensure the analgesic should be taken by the simplest route of administration (e.g., by the mouth), on a regular basis (e.g., by the clock), according to the type and intensity of the pain (e.g., by the ladder) and by the patient whenever possible $\left[{ }^{7,36}\right]$.

An updated WHO ladder, e.g., a four-steps ladder (Fig. 2), as opposed to the 1986 "ladder", reflects the advances in non-opioid modalities for achieving better pain relief. The integrative medicine therapies can be adopted in each step for reducing or even stopping the use of analgesics for all types of pain. If the non-opioids and weak opioids fail, minimally invasive interventions in step 3 can be recommended before upgrading to strong opioids. The revised four-step analgesic ladder aligned with integrative medicine principles and minimally invasive interventions is recommended for control of chronic non-cancer pain, including musculoskeletal pain, in order to integrate multimodality therapies for patients who are suffering from pain and can be a key factor in mitigating the opioid epidemic [53].
List of pharmacological treatments $[6,36,37,43,44]$

1. Simple analgesics

Non-steroidal analgesic and antipyretics

ASA

Acetaminophen (paracetamol)

Non-steroidal analgesic and anti-inflammatory (NSAIDs)

Non-selective COX inhibitors

Selective COX-2 inhibitors

2. Opioids

Weak opioids

Strong opioids

Mixed agonist-antagonists

3. Adjuvants

Anticonvulsant

Gabapentin

Pregabalin

Carbamazepine

Antidepressants

Tricyclic antidepressants, e.g., amitriptyline

SNRIs e.g., duloxetine

Local anesthetics

Lidocaine

Mexiletine

Topical agents

Lidocaine patch or solution

Diclofenac gel or patch

Musculoskeletal agents

Baclofen

Tizanidine

Cyclobenzaprine

Anxiolytics

Others

NMDA inhibitors, e.g., ketamine

$\alpha-2$ Agonists e.g., clonidine

Calcitonin

Others 
Table 1 Summary of the non-opioid analgesics

\begin{tabular}{|c|c|c|c|c|}
\hline Drug & Route & Dose & Duration & Comments \\
\hline $\begin{array}{l}\text { Acetaminophen } \\
\text { (paracetamol) } \\
{[40,54]}\end{array}$ & $\mathrm{PO} / \mathrm{IV}$ & $\begin{array}{l}10-15 \mathrm{mg} / \mathrm{kg} \text { (average } \\
1 \mathrm{~g})\end{array}$ & $6-8 \mathrm{~h}$ & $\begin{array}{l}\text { Analgesic, anti-pyretic } \\
\text { Has a wide safety margin } \\
\text { Used for s wide range of painful } \\
\text { conditions and in all age groups } \\
\text { Overdose may cause hepatic toxicity }\end{array}$ \\
\hline \multicolumn{5}{|c|}{ NSAIDs: non-selective $[36,40,43]$} \\
\hline Ibuprofen & $\mathrm{PO}$ & $400 \mathrm{mg}$ & $4-6 h$ & Analgesic, anti-inflammatory \\
\hline $\begin{array}{l}\text { Lornoxicam (not } \\
\text { available in the } \\
\text { USA) }\end{array}$ & $\mathrm{PO}$ & $8 \mathrm{mg}$ & $\begin{array}{l}8 \mathrm{~h} \\
\text { Maximum daily } \\
\text { dose } \\
16-24 \mathrm{mg}\end{array}$ & $\begin{array}{l}\text { Effective for mild-to-moderate pain } \\
\text { Ceiling effect to analgesia } \\
\text { Gastric upset, renal dysfunction, } \\
\text { contraindicated in bronchial asthma }\end{array}$ \\
\hline Naproxen & $\mathrm{PO}$ & $250-500 \mathrm{mg}$ & $6-8 \mathrm{~h}$ & ${ }^{*}$ Increase intraoperative bleeding \\
\hline Ketorolac & IV & $15-30 \mathrm{mg}$ & $6 \mathrm{~h}$ & \\
\hline Diclofenac & $\begin{array}{l}\text { Topical } 1 \% \\
\text { or TD } \\
1.3 \%\end{array}$ & $\begin{array}{l}\text { Gel: } 2-4 \text { g; } \max \\
32 \mathrm{~g} / \text { day/body or } \\
8 \mathrm{~g} / \text { day/joint } \\
\text { Patch: } 180 \mathrm{mg}\end{array}$ & $\begin{array}{l}\text { Gel: } 4-6 \mathrm{~h} \\
\text { Patch: } 12 \mathrm{~h}\end{array}$ & $\begin{array}{l}\text { Effective especially for osteoarthritic pain. } \\
\text { Patch used for acute sprains and strains } \\
\text { Topical formulation limits systemic side } \\
\text { effects }\end{array}$ \\
\hline \multicolumn{5}{|c|}{ Selective COX-2 inhibitors (COXIBs) $[37,43,45]$} \\
\hline Celecoxib & $\mathrm{PO}$ & $200-400 \mathrm{mg}$ & $12-24 \mathrm{~h}$ & Analgesic, anti-inflammatory \\
\hline $\begin{array}{l}\text { Parecoxib (not } \\
\text { available in the } \\
\text { USA) }\end{array}$ & $\mathrm{IV}^{*}$ & $20-40 \mathrm{mg}$ & $12 \mathrm{~h}$ & $\begin{array}{l}\text { Effective for mild-to-moderate pain } \\
\text { Selective COX-2 inhibitors, fewer gastric } \\
\text { side effects. Renal dysfunction } \\
\text { Not recommended in cardiac and } \\
\text { hypertensive patients } \\
{ }^{*} \text { May cause allergy }\end{array}$ \\
\hline
\end{tabular}

\section{Commonly Used Analgesics for Musculoskeletal Pain}

\section{(1) Non-opioid analgesics (Table 1)}

- Acetaminophen (paracetamol)

Paracetamol is thought to act both centrally and peripherally. It reduces prostaglandin synthesis from arachidonic acid via inhibition of the cyclooxygenase isoenzymes COX-1 and COX-2. Paracetamol should be considered alone or in combination with NSAIDs in the management of pain in patients with MSK. Generally, paracetamol has been used for pain relief across a wide range of indications because of its relative effectiveness in many pain conditions, high tolerability, and minimal adverse effects $[41,54]$.

Acetaminophen is conditionally recommended for patients with knee, hip, and/or hand OA. A meta-analysis has suggested that the use of acetaminophen as monotherapy may be ineffective [55]. For those with intolerance of 


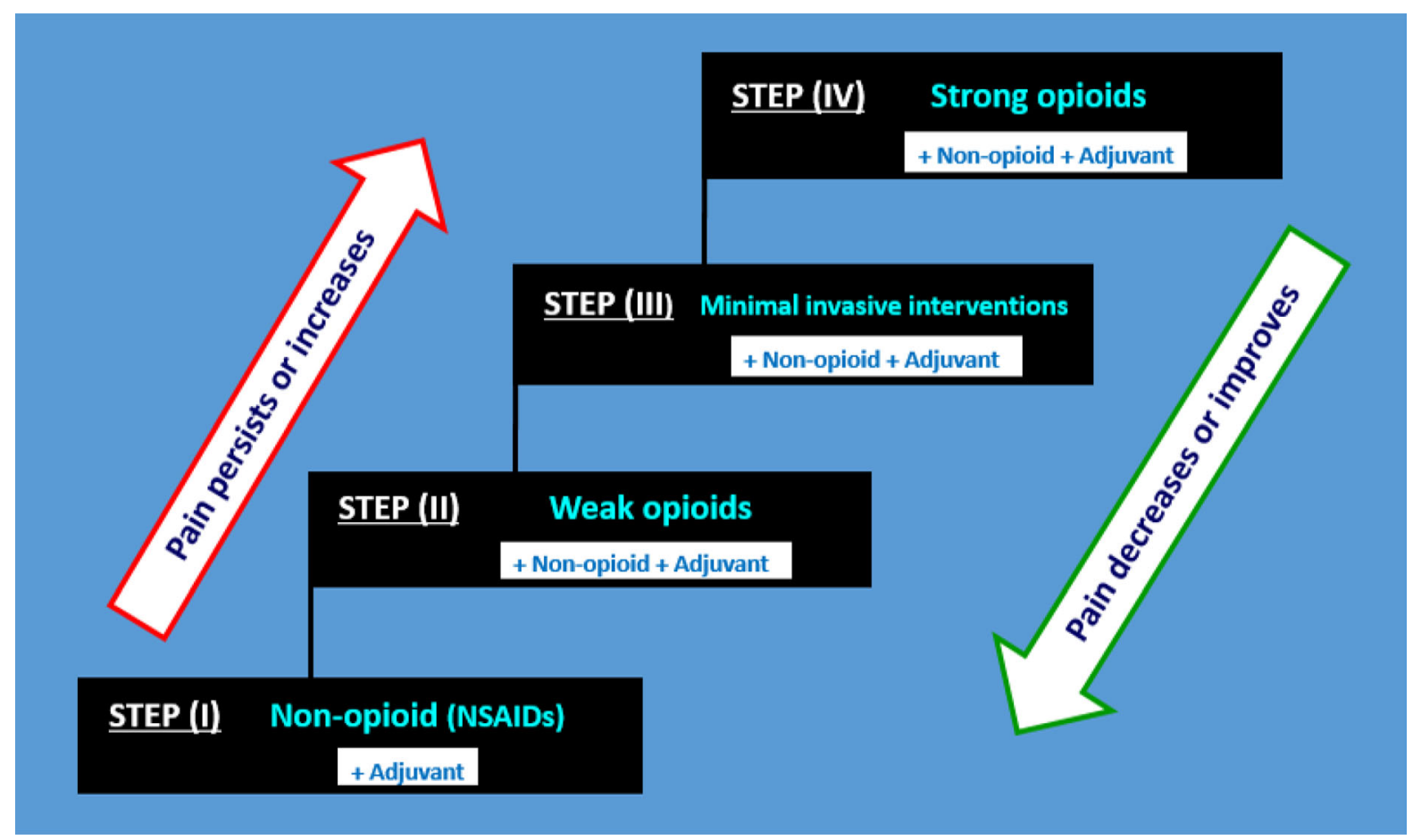

Fig. 2 Updated WHO ladder system

or contraindications to the use of NSAIDs, acetaminophen may be appropriate for shortterm use. Regular monitoring for hepatotoxicity is required for patients who receive acetaminophen on a regular basis and beyond the maximum dosage of $3 \mathrm{~g}$ daily [56].

Acetaminophen is available in a fixed-dose combination product with codeine with $30-60 \mathrm{mg}$ and acetaminophen 300-1000 mg, marketed under the tradename Tylenol-3.

\section{- NSAIDs}

NSAIDs should be considered in the treatment of patients with chronic non-specific LBP and osteoarthritis (OA) [40]. Oral NSAIDs are strongly recommended for patients with knee, hip, and/or hand OA. Oral NSAIDs remain the mainstay of pharmacologic management of OA, and their use is strongly recommended. A large number of trials have established their shortterm efficacy. Oral NSAIDs are the initial oral medication of choice in the treatment of OA, regardless of anatomic location, and are recommended over all other available oral medications $[55,56]$.

Non-specific NSAIDs
These have analgesic and anti-inflammatory properties and may be used as the sole method of treatment for mild-to-moderate pain. They have a "ceiling effect" to analgesia, and may lead to an increase in adverse effects $[36,57]$. Clinical considerations for the safety of longterm use of NSAIDs include appropriate patient selection, regular monitoring for the development of potential adverse gastrointestinal, cardiovascular, and renal side effects, and potential drug interactions. Doses should be as low as possible, and NSAID treatment should be continued for as short a time as possible [56]. Prolonged use of NSAID treatment is also associated with other adverse effects including inhibition of platelet function and increased bleeding time, as well as bronchospasm following the administration of aspirin and other NSAIDs in some patients with asthma $[36,57]$.

$\bigcirc$ COX-2 selective inhibitors $(\mathrm{COX}-2)$

COX-2 selective inhibitors refer to a class of analgesic and anti-inflammatory drugs. COX-2 is found in inflammatory cells, tissue damage, synovia of joints, endothelium, and the CNS $[37,43]$. 
COX-2 selective inhibitors are as effective as classical NSAIDs for the treatment of mild-tomoderate pain. However, COX-2 had fewer gastrointestinal side effects than traditional NSAIDs, but long-term use of COX-2 inhibitors may be associated with increased risk of cardiovascular side effects and this should be taken into account especially in cardiac and susceptible patients [40]. The most commonly used COX-2 selective inhibitor in the United States is celecoxib.

\section{O Topical NSAIDs}

Topical NSAIDs, like topical diclofenac, are effective for reducing musculoskeletal pain and should be considered in the treatment of patients with chronic pain conditions, particularly in patients who cannot tolerate oral NSAIDs [58]. Topical NSAIDs are strongly recommended for patients with knee OA and conditionally recommended for patients with hand OA. In the United States, the FDA approved topical diclofenac in 2007 for osteoarthritic pain, responsive in the joints of the hand, knees, and feet in particular. Topical NSAIDs are preferred and should be considered prior to the use of oral NSAIDs because they are associated with the least systemic exposure. In hip OA, the depth of the joint beneath the skin surface suggests that topical NSAIDs are unlikely to confer benefit [56].

(2) Opioids: (Table 2)

Opioids produce their effect by acting as agonists at opioid receptors, which are found in the brain, spinal cord, and sites outside the CNS. There are three types of opioid receptors: mu $(\mu)$, delta $(\delta)$, and kappa $(\kappa)[32,44]$.

Opioids are available in different forms and can be used by different routes of administrations, e.g., oral, sublingual, IV, IM, SC, transdermal, or neuraxial.

The main indication for opioids is to provide analgesia and pain relief for both cancer and non-cancer pain. At the same time, most opioids have a similar spectrum of adverse effects, e.g., respiratory depression, sedation, nausea/ vomiting, and constipation $[44,59,60]$.

It is important to know that opioids are not the first-line therapy for chronic pain; the risks, benefits, and availability of non-opioid treatments should be addressed first with patients
[61]. Opioids should be considered for short- to the medium-term treatment of carefully selected patients with chronic non-malignant pain, for whom other therapies have been insufficient and the benefits may outweigh the risks of serious harms such as addiction, overdose or even death. Patients prescribed opioids should be advised of the likelihood of common side effects such as nausea and constipation [40].

The dramatic rise in the prescription of opioids, resulting from the increase in the prevalence of chronic pain, and the increase in dosage and frequency of prescriptions lead to overdose and death. The risks associated with opioid use may have created a growing need for clinical guidance on decision-making for opioid prescriptions [6].

The ongoing opioid crisis lies at the intersection of two substantial public health challenges "reducing the burden of suffering from pain and containing the rising toll of the harms that can result from the use of opioid medications" [62]. The influence of polysubstance abuse and the use of illicit opioids like synthetic fentanyl may also contribute heavily to overdose deaths as discussed above.

In a systematic review, three studies from the USA found that the prevalence of opioid dependence ranged from 3 to $26 \%$ in patients who were using opioids for chronic pain [63].

Another systematic review found a wide range of estimates of the rates of misuse of opioids used to treat patients with chronic pain, depending upon, among other things, study setting and case definition. It concluded that rates of misuse averaged between 8 and 12\% [64].

(3) Adjuvants analgesics: (Table 3)

- Anticonvulsants (e.g., gabapentin, pregabalin, carbamazepine)

These medications were originally developed to treat seizures, but they are used to treat some forms of pain including neuropathic pain. Gabapentin and pregabalin are effective for the treatment of patients with neuropathic pain, and FDA approved in the United States for neuropathic pain conditions like spinal cord injury, shingles, and diabetic neuropathy. These medications have a more tolerable side-effect profile compared to other anti-convulsants. 
Table 2 Summary of the commonly used opioids

\begin{tabular}{|c|c|c|c|c|c|}
\hline OPIOID & Route & Dose & Onset & Duration & Comments \\
\hline \multirow{5}{*}{$\begin{array}{r}\text { Morphine } \\
{[40,78]}\end{array}$} & $\mathrm{PO}$ & $15-60 \mathrm{mg}$ & $45 \mathrm{~min}$ & $4-5 \mathrm{~h}$ & Poor oral potency \\
\hline & MS & $30-60$ & $45 \mathrm{~min}$ & $8-12 \mathrm{~h}$ & Histamine release $(+)$ \\
\hline & Contin & & & & Sedation, N/V \\
\hline & IV & $5-15 \mathrm{mg}$ & $10 \mathrm{~min}$ & $3.5-4 \mathrm{~h}$ & Respiratory depression \\
\hline & & & & & $\begin{array}{l}\text { Active metabolites may accumulate } \\
\text { in renal failure }\end{array}$ \\
\hline \multirow{7}{*}{$\begin{array}{l}\text { Fentanyl } \\
\qquad[40,78]\end{array}$} & Sublingual & $100-400 \mathrm{mcg}$ & $5-10 \mathrm{~min}$ & $60 \mathrm{~min}$ & Rapid onset, short duration \\
\hline & & & & & Respiratory depression + \\
\hline & IV & $5-150 \mathrm{mcg}$ & $3-5 \mathrm{~min}$ & $30-60 \mathrm{~min}$ & Very rapid onset, short duration \\
\hline & & & & & Better used by PCA \\
\hline & & & & & Respiratory depression \\
\hline & TTS & $25-100 \mathrm{mcg}$ & $17-24 \mathrm{~h}$ & $72 \mathrm{~h}$ & Not suitable for acute pain \\
\hline & & & & & Main indication in cancer pain \\
\hline \multirow{3}{*}{$\begin{array}{c}\text { Meperidine } \\
\text { (pethidine) } \\
{[40,78]}\end{array}$} & IV & $50-100 \mathrm{mg}$ & $30 \mathrm{~min}$ & $3-4 h$ & Effective for visceral pain \\
\hline & & & & & Low safety profile, e.g., more $\mathrm{N} / \mathrm{V}$ \\
\hline & & & & & $\begin{array}{l}\text { High addiction liability, } \\
\text { neurotoxic metabolite } \\
\text { (norpethidine) in renal } \\
\text { impairments }\end{array}$ \\
\hline \multirow{8}{*}{$\begin{array}{c}\text { Oxycodone } \\
{[40,78]}\end{array}$} & $\mathrm{PO}$ & $5-10 \mathrm{mg}$ IR & $5-10 \mathrm{~min}$ & $3-4 h$ & Good oral analgesic \\
\hline & & & & & Effective for incident pain \\
\hline & $\mathrm{PO}$ & $10-20 \mathrm{mg}$ & $15-30 \mathrm{~min}$ & $8-12 \mathrm{~h}$ & Good oral analgesic \\
\hline & & CR (Oxycontin) & & & Rapid onset, long duration \\
\hline & & & & & $\begin{array}{l}\text { Effective for visceral and } \\
\text { neuropathic pain }\end{array}$ \\
\hline & & & & & Less $\mathrm{N} / \mathrm{V}$ \\
\hline & & & & & Respiratory depression \\
\hline & IV & $5-15 \mathrm{mg}$ & $3-6 \mathrm{~min}$ & $4-6 h$ & Rapid onset, long duration \\
\hline
\end{tabular}


Table 2 continued

\begin{tabular}{|c|c|c|c|c|c|}
\hline OPIOID & Route & Dose & Onset & Duration & Comments \\
\hline $\begin{array}{c}\text { Methadone } \\
{[40,78]}\end{array}$ & $\mathrm{PO}$ & $5-10 \mathrm{mg}$ & $15-45 \mathrm{~min}$ & $6-8 \mathrm{~h}$ & $\begin{array}{l}\text { Good oral analgesic } \\
\text { Prolonged elimination } \\
\text { Effective for neuropathic pain } \\
\text { Detoxification treatment } \\
\text { Very } \\
\text { unpredictable pharmacokinetics } \\
\text { with considerable interindividual } \\
\text { variation } \\
\text { Respiratory depression } \\
\text { Prolongation of QT interval }\end{array}$ \\
\hline $\begin{array}{l}\text { Buprenorphine } \\
{[40,79]}\end{array}$ & TD patch & $5,10,20 \mathrm{mcg}$ & $26-36 \mathrm{~h}$ & 1 week & $\begin{array}{l}\text { Schedule III partial } \mu \text {-opioid } \\
\text { agonist } \\
\text { Effective and safer than full } \mu \text { - } \\
\text { agonist } \\
\text { Suitable for pain that is severe } \\
\text { enough to require daily, around- } \\
\text { the-clock, long-term opioids } \\
\text { Has a delayed onset, very long and } \\
\text { stable analgesia, } \\
\text { Ceiling effect for respiratory } \\
\text { depression but not to analgesia } \\
\text { Safe in elderly patients and renal } \\
\text { impairments } \\
\text { Less addiction liability } \\
\text { No withdrawal effects } \\
\text { Potentiates anti-depressant and } \\
\text { anti-anxiety effects } \\
\text { It is not immunosuppressive }\end{array}$ \\
\hline
\end{tabular}


Table 2 continued

\begin{tabular}{|c|c|c|c|c|c|}
\hline OPIOID & Route & Dose & Onset & Duration & Comments \\
\hline $\begin{array}{l}\text { Tramadol } \\
\qquad[40,55,56]\end{array}$ & $\begin{array}{l}\text { PO } \\
\text { IV }\end{array}$ & $\begin{array}{l}50-200 \mathrm{mg} \\
50-100 \mathrm{mg}\end{array}$ & $\begin{array}{l}40 \mathrm{~min} \\
10-15 \mathrm{~min}\end{array}$ & $\begin{array}{l}4-6 h \\
3-4 h\end{array}$ & $\begin{array}{l}\text { Weak opioid, with additional } \\
\text { effects on noradrenergic and } \\
\text { serotonergic systems } \\
\text { Has an active metabolite } \\
\text { Effective for moderate pain } \\
\text { Used in MSK pain when other } \\
\text { analgesics are contraindicated or } \\
\text { ineffective } \\
\text { Side effects includes: concerns of } \\
\text { addiction, N/V }\end{array}$ \\
\hline $\begin{array}{l}\text { Codeine } \\
\qquad[40,80]\end{array}$ & $\mathrm{PO}$ & $30-60 \mathrm{mg}$ & $45 \mathrm{~min}$ & $3-4 h$ & $\begin{array}{l}\text { Weak opioid. It is inactive } \\
\text { prodrug; converted in the liver } \\
\text { to morphine by the enzyme } \\
\text { CYP2D6 } \\
\text { Sedation, N/V+++ } \\
\text { High side effect profile }\end{array}$ \\
\hline $\begin{array}{l}\text { Tylenol-3 } \\
{[40,80]}\end{array}$ & $\mathrm{PO}$ & $\begin{array}{l}\text { Codeine } \\
30-60 \mathrm{mg}+\text { paracetamol } \\
300-1000 \mathrm{mg}\end{array}$ & $0.5-1 \mathrm{~h}$ & $4-6 h$ & $\begin{array}{l}\text { Effective for mild-to-moderate } \\
\text { pain } \\
\text { Risks of opioid addiction, abuse }\end{array}$ \\
\hline
\end{tabular}

There is recent concern of respiratory depression when this medication is used in conjunction with CNS depressants, including opioids, and in patients with baseline respiratory impairment. Flexible dosing may improve tolerability. Perioperative gabapentinoids are a useful component of perioperative multimodal analgesia and have been shown to reduce opioid requirements. Pregabalin is recommended also for the treatment of patients with fibromyalgia $[65,66]$.

Gabapentinoids bind to the $\alpha 2-\delta$-subunit of neuronal voltage-gated calcium channels and thus reduce the influx of calcium ions in hyperexcitable neuronal states $[65,66]$. Carbamazepine is approved by the FDA in the United States for the treatment of trigeminal neuralgia. It seems to have a specific effect, however potential adverse events should be discussed [40].
- Anti-depressants

Tricyclic antidepressants (TCA) (e.g., amitriptyline and nortriptyline) have an analgesic effect that is demonstrated to be independent of their antidepressant effect. The pharmacological actions of TCAs can be linked to their effect as a calcium channel antagonist, sodium channel antagonist, and their NMDA receptor antagonist effect. More specifically, the analgesic effect is believed to be due to the presynaptic reuptake inhibition of the monoamines such as serotonin and norepinephrine $[38,65,66]$. While some state that tricyclic antidepressants should not be used for the management of pain in patients with chronic low back pain $[65,66]$, recent studies have indicated that low doses of amitriptyline may be an effective treatment for low back pain [67]. There is also anecdotal evidence that 
Table 3 Summary of the adjuvant analgesics

Antidepressants $[40,65,66]$

$$
\begin{array}{llll}
\text { Amitriptyline } & \text { PO } & 10-150 \mathrm{mg} & 24 \mathrm{~h} \\
\text { Nortriptyline } & \text { PO } & 25-100 \mathrm{mg} & 24 \mathrm{~h}
\end{array}
$$

Duloxetine $\quad$ PO $\quad 60 \mathrm{mg} \quad 24 \mathrm{~h}$

Anticonvulsants $[40,65,66]$

$\begin{array}{llll}\text { Gabapentin } & \text { PO } & 200-400 \mathrm{mg} & \text { TID } \\ \text { Pregabalin } & \text { PO } & 75-300 \mathrm{mg} & \text { BID }\end{array}$

Carbamazepine $\quad$ PO $\quad 400-1200 \mathrm{mg} \quad 24 \mathrm{~h}$

Others

$\begin{array}{llll}\begin{array}{l}\text { Dexamethasone } \\ {[81]}\end{array} & \begin{array}{c}\mathrm{PO} / \\ \mathrm{IV}^{*}\end{array} & 4-8 \mathrm{mg} & 8-12 \mathrm{~h} \\ \begin{array}{l}\text { Prednisolone } \\ {[81]}\end{array} & \mathrm{PO} & 10-40 \mathrm{mg} & \mathrm{BID} \\ \begin{array}{c}\text { Lidocaine } \\ \text { (Versatis) [73] }\end{array} & \text { TD } & 5 \% \text { patch } & \begin{array}{l}12 \mathrm{~h} \text { on } \\ \text { then } 12 \mathrm{~h} \text { off }\end{array} \\ \begin{array}{l}\text { Capsaicin [74] } \\ \text { TD }\end{array} & 8 \% \text { patch } & \begin{array}{c}\text { Analgesia occurs within few days } \\ \text { and may last for few months }\end{array}\end{array}$

Tricyclic antidepressants

Mainly used for neuropathic pain, fibromyalgia

Side effects: drowsiness, anticholinergic actions

SNRIs

Mainly used for neuropathic pain, PDPN, fibromyalgia, O.A.

Not sedative, but causes nausea

Anticonvulsants

First-line treatment of neuropathic pain

May be used for pain

Cause: drowsiness and sedation

Used for trigeminal neuralgia

It has a narrow therapeutic index: liver toxicity, skin reaction, allergy, anemia

Corticosteroids

Improves analgesia and reduces opioid requirements

* Reduces PONV

First-line treatment localized neuropathic pain and $\mathrm{PHN}$

Selective cases of MSK pain

Peripheral neuropathic pain and PHN

Burning or itching sensation nortriptyline may have a beneficial effect, and further research may be indicated in this area.

Serotonin norepinephrine re-uptake inhibitor (SNRI) (e.g., duloxetine 60-120 mg) should be considered for the treatment of patients with a variety of chronic pain conditions such as diabetic neuropathic pain, fibromyalgia, osteoarthritis, and LBP [61].
Selective serotonin re-uptake inhibitors (SSRIs) such as fluoxetine (20-80 mg) may be considered for the treatment of patients with fibromyalgia, although it has not been successful in treating many forms of neuropathic pain $[6,61]$.

- Musculoskeletal agents 
Musculoskeletal agents commonly used for pain treatment include baclofen, tizanidine, and cyclobenzaprine. Baclofen is a gammaaminobutyric acid (GABA) agonist whose method of action is not fully understood, but can inhibit monosynaptic and polysynaptic reflexes at the spinal level. It is used as a skeletal muscle relaxant as well as in the treatment of spasticity. Tizanidine is a central alpha-2 adrenergic receptor agonist with resulting inhibition of spasticity by increasing presynaptic inhibition. Cyclobenzaprine is a muscle relaxant thought to act primarily via 5-HT2 receptor antagonism on the brainstem, impacting both gamma and alpha motor neurons. Carisoprodol is metabolized to meprobamate, which is both sedating and possibly addictive, so the use of carisoprodol is not recommended, particularly because alternatives are available [68].

- Anxiolytics

Anti-anxiety medications are often prescribed to treat the anxiety that accompanies acute pain as well as anxiety resulting from fluctuations in chronic pain. They may also be prescribed for co-morbid anxiety disorders such as generalized anxiety disorder, panic disorder, post-traumatic stress disorder, and agoraphobia, which as a group have a prevalence estimated in the range of $30 \%$ in patients with chronic pain [69]. Some shorter-acting benzodiazepines carry a risk of abuse and addiction, for example lorazepam. Concurrent use of opioids and respiratory depressants like benzos have been implicated in a higher risk of adverse side effects, especially overdose-related deaths. There is poor and little evidence to support long-term benzodiazepine usage, and treatment should therefore be given for the short term until the patient can be placed on the appropriate long-term treatment, i.e., SSRIs [70].

- Alpha-2-adrenergic agonists

The analgesic activity of $\alpha 2$-agonists may be mediated by both supraspinal and spinal mechanisms. These drugs decrease dorsal horn neuronal firing and inhibit substance $\mathrm{P}$ release by affecting the $\alpha 2 \mathrm{~A}$ and $\alpha 2 \mathrm{C}$ subgroups in the central nervous system, resulting in sedation, analgesia, and sympatholytic effects [71]. Clonidine and tizanidine have been used in the treatment of chronic pain disorders. Tizanidine has also been used in myofascial pain disorders as well as for painful muscle spasms [64]. Dexmedetomidine is eight times more specific for $\alpha 2$-adrenoceptors than clonidine, but has been studied for chronic pain $[66,72]$.

- Topical agents

Topical lidocaine patches (5\%) may be used for localized nociceptive pain, neuropathic pain, and post-herpetic neuralgia. These are worn $12 \mathrm{~h}$ on and $12 \mathrm{~h}$ off. Few side effects such as skin redness and irritation may be reported [73].

Topical capsaicin patches (8\%)

Evidence supports that capsaicin can be used for the treatment of both chronic neuropathic and musculoskeletal pain. The main adverse reaction with topical capsaicin patches is localized skin irritation. Due to its poor efficacy, it should be considered in the treatment of patients when first-line pharmacological therapies have been ineffective or not tolerated [74]. Topical capsaicin is FDA approved for the treatment of peripheral diabetic neuropathy of the feet, and postherpetic neuralgia (PHN) in the United States [75].

- Bone marrow concentrate (BMC)

The use of bone marrow concentrate for the treatment of musculoskeletal disorders has become increasingly popular over the last several years. Typically, bone marrow is obtained by iliac crest aspiration, and contains progenitor cells like mesenchymal stem cells, as well as cytokine and growth factors [76]. Studies have suggested good-to-great pain relief with BMC use, and injection is a safe procedure when performed by trained physicians with the appropriate precautions under image guidance utilizing a sterile technique.

The position statement for the use of homologous BMC in MSK pain developed by Manchikati et al. recommends a method of preparation with minimal manipulation and suggests moderate and emerging evidence of beneficial utility in various musculoskeletal and spinal conditions [77]. Evidence for use of BMC is highest in osteoarthritis of the knee (level II), moderate for knee cartilage conditions or for disc injections for degenerative disc disease (level III), and limited evidence for all other conditions when performed by trained 
physicians under image guidance with sterile technique and precautions [77].

(II) Non-pharmacological

\section{(1) Physical modalities}

These modalities may be valuable and successful in the management of both acute and chronic pain. Muscle spasm is usually the main cause of pain; heat and cold application reduces spasmodic muscle shortening, which in turn may be caused by direct muscular trauma or underlying primary neurologic or skeletal disease. Passive treatment programs such as hot packs, massage, and ultrasound may be appropriate for a short period of time; however, a home exercise program, stretching, and selfapplied modalities should be implemented early [82-84]. There are no large landmark clinical trials of these modalities so evidence must be considered as limited.

\section{- Cryotherapy}

Therapeutic cold is applied directly to an injured area to reduce hemorrhage and vasodilation, decreases the local inflammatory response, edema production, and pain perception [85]. The PRICE (protection, rest, ice, compression, and elevation) method is commonly prescribed for acute sports-related injuries as well as chronic painful conditions [86].

Cryotherapy is not recommended in patients with peripheral vascular disease (e.g., Raynaud's disease). Also, prolonged exposure to cold should be avoided on superficial nerves such as ulnar and peroneal nerves at the medial elbow and head of the fibula $[85,86]$.

- Heat therapy

Heat application, in both subacute and chronic pain conditions, produces increased collagen extensibility, increased blood flow, metabolic rate, and inflammation resolution. Decreased joint stiffness, muscle spasm, and pain are also positive effects of heat therapy. Heat raises the pain threshold and acts directly on the muscle spindle, decreasing spindle excitability [87]. Therapeutic heat application is used in combination with prolonged stretch to reduce musculoskeletal contractures, joint stiffness, and chronic inflammatory diseases, thus leading to decreased pain and increasing range of motion and function $[88,89]$.
Superficial heat therapy is contraindicated in cases with sensory impairment, vascular insufficiency, malignancy and infection, while deep heat is contraindicated in pregnancy, sensory deficit, and metal implants [50].

- Transcutaneous electrical nerve stimulation therapy (TENS)

"TENS" is based on the gate control theory of pain from Melzack and Wall, where the preferential activation of large $A \beta$-fibers inhibits the transmission of painful impulses [90]. It has been used to manage acute and chronic pain, e.g., postoperative pain, complex regional pain syndrome, phantom limb pain, and peripheral nerve injury [91-93]. It is contraindicated in patients with a cardiac pacemaker [93]. TENS has been used anecdotally for use in low back pain, but studies show conflicting recommendations on the matter. TENS has been shown to be effective in osteoarthritic and neuropathic pain [94].

\section{- Acupuncture}

Acupuncture is an ancient Chinese therapy practiced for more than 2500 years to cure disease and relieve pain. It depends on the use of thin metal needles that are inserted into specific body sites and stimulated manually or electrically. Acupuncture is considered an invasive procedure and needs a professional physician or practitioner to perform it. There is no evidence that acupuncture is more effective than other treatments such as NSAIDs for low back pain or neck pain $[95,96]$. Side effects are localized hyperemia, syncopal attacks, and hematoma [97].

\section{- Therapeutic exercise}

Acute injuries of the musculoskeletal system may lead to contraction and shortening of the muscles as a protective mechanism. So, treatment usually consists of immobilization, compression, and cryotherapy. When pain decreases, mobilization should be regained gradually, but if muscle became chronically shortened and contracted, additional pain will result. The best treatment in such cases is combined gradual stretching and strengthening exercises. Patient education is mandatory about a therapeutic exercise regimen at home once therapeutic sessions have ceased $[98,99]$. 
Therapeutic exercise consists of passive movements, active-assistive exercises, active exercises, stretching, and relaxation exercises. These may be used in combination with other physical modalities [100, 101].

\section{(2) Psychological}

There is growing evidence that a range of psychological factors can contribute to the experience and impact of pain, as well as the development of persisting pain. These factors should be considered and targeted by specific treatments, e.g., cognitive behavioral therapy, explanation, reassurance, stress reduction, and counseling [102, 103].

\section{(3) Pain interventions}

Pain interventions are minimally invasive procedures that relieve acute and chronic pain and minimize the use of analgesics when appropriately indicated. Neural blockade can be used for diagnostic, prognostic, or therapeutic purposes. Image guidance tools such as ultrasound, C-arm, CT, or MRI can be used during the intervention when clinically indicated. Most of the interventions are conducted on an outpatient or day-care basis [32, 104, 105].

Therapeutic options include:

- Medications, e.g., local anesthetics, steroids, opioids, Botulinum toxin, $\alpha-2$ adrenergic agonists.

- Destructive: neurolytics (alcohol or phenol)

- Physical: Radiofrequency (pulsed or thermal RF) and cryo-analgesia

Intervention trials should focus on outcomes based on six core domains defined by the IMMPACT (Initiative on Methods, Measurement, and Pain Assessment in Clinical Trials) to be: pain, physical functioning, emotional functioning, participant rating of improvement and satisfaction with treatment, symptoms and adverse events, and participant disposition [106].

A list of the common pain interventions that can be used for the management of MSK pain is shown in Table 4. Additionally, in other chronic pain conditions, there is often overlapping musculoskeletal pain. Therefore, the co-existence of underlying neuropathic or other pain syndromes often requires the use of these interventions.

\section{(4) Surgical interventions [19, 32]}

- Surgical procedures for the primary lesion or pathology.

- Neuro-surgical procedures for pain management.

\section{CONCLUSIONS}

Musculoskeletal pain is a collective term for a variety of conditions of different etiologies and different disease trajectories, but taken together they represent a substantial burden on patients, society, and the healthcare system. Musculoskeletal pain can be secondary to (or exacerbated by) multiple etiologies and often responds to a multimodal therapeutic approach. Musculoskeletal pain in different body areas shares similar features, prognostic factors, and clinical course, and therefore it may be possible to identify consistent overarching recommendations for assessment and management.

Patient screening is an important step in identifying the groups at risk or being most vulnerable. Identifying common recommendations could be a useful way to improve the quality of care. Based on the literature, the authors support a treatment hierarchy that involves non-pharmaceutical conservative management for chronic musculoskeletal pain with home exercises along with acetaminophen and/or NSAIDs initially. Should this conservative management not manage pain appropriately, structured therapy courses and pharmaceutical intervention may then be indicated. Should this continue to provide little to no pain relief, the use of minimally interventional procedures may be indicated along with continued therapy.

While drug therapy for musculoskeletal pain is frequently prescribed and often helpful, it is associated with important risks and not all patients respond. When pharmacological therapy is to be incorporated, it should be in the context of a shared decision-making model where both patient and prescriber evaluate the risks and benefits of various therapeutic choices.

Holistic care for patients involves treating musculoskeletal pain in the context of the 
Table 4 List of the interventions for chronic pain management

\begin{tabular}{|c|c|c|}
\hline Pain procedure & Indications and technique & Drawbacks \\
\hline $\begin{array}{l}\text { Trigger point injection } \\
{[107,108]}\end{array}$ & $\begin{array}{l}\text { Palpable, tense bands } \\
\text { Can be used to treat headache, myofascial pain } \\
\text { syndrome, LBP } \\
\text { Local anesthetic } \pm \text { steroids } \\
\text { or dry needling } \\
\text { No strong evidence of efficacy [108] }\end{array}$ & Pain on injection \\
\hline $\begin{array}{l}\text { Facet joint injection/ } \\
\text { Medial branch block } \\
\text { (FJI/MBB) }[109-111]\end{array}$ & $\begin{array}{l}\text { Facet arthropathy, somatic (non-radicular) } \\
\text { pain, trauma } \\
\text { By: local anesthetics } \pm \text { steroids, neurolytics, } \\
\text { RF, or cryo } \\
\text { Fluoroscopy or ultrasound-guided } \\
\text { Approach: lumber, thoracic, or cervical } \\
\text { Evidence for lumbar (level I), cervical and } \\
\text { thoracic facet joint nerve blocks (level II) } \\
\text { [111] }\end{array}$ & $\begin{array}{l}\text { Nerve irritation } \\
\text { Spread of injection to the epidural space } \\
\text { IV injection }\end{array}$ \\
\hline $\begin{array}{l}\text { Sacroiliac joint injection } \\
\qquad(\mathrm{SIJ})[112]\end{array}$ & $\begin{array}{l}\text { Sacro-iliac joint pain, arthritis, trauma } \\
\text { By: local anesthetics }+ \text { steroids } \\
\text { Or thermal or cooled RF } \\
\text { Fluoroscopy or ultrasound-guided } \\
\text { Beneficial for short-term SIJ-mediated pain } \\
\text { control; little risk }[113]\end{array}$ & $\begin{array}{l}\text { Pain on injection } \\
\text { Epidural injection } \\
\text { Sacral nerve root blockade } \\
\text { Painful subperiosteal injection }\end{array}$ \\
\hline $\begin{array}{l}\text { Piriformis injection } \\
{[\quad[114,115]}\end{array}$ & $\begin{array}{l}\text { Piriformis syndrome is diagnosis of exclusion } \\
\text { Unilateral or bilateral buttock pain with } \\
\text { fluctuation, no low back pain or pain on } \\
\text { palpation of axial spine, pain on palpation of } \\
\text { the sciatic notch area. Negative straight leg } \\
\text { rise, pain with prolonged sitting, positive } \\
\text { FAIR or Freiberg or Beatty sign } \\
\text { Injection of the piriformis usually done by the } \\
\text { use of local anesthetic }+ \text { steroids. Botulinum } \\
\text { toxin recently used } \\
\text { It is conducted under ultrasound, fluoroscopy } \\
\text { guidance, or EMG (electromyography) } \\
\text { There is a lack of double-blind RCTs in order } \\
\text { to determine the efficacy }\end{array}$ & $\begin{array}{l}\text { Failure } \\
\text { Sciatic nerve block } \\
\text { Infection (rare) }\end{array}$ \\
\hline
\end{tabular}


Table 4 continued

\begin{tabular}{|c|c|c|}
\hline Pain procedure & Indications and technique & Drawbacks \\
\hline $\begin{array}{l}\text { Epidural steroid } \\
\text { injection (ESI) } \\
{[116-120]}\end{array}$ & $\begin{array}{l}\text { The most common pain procedure } \\
\text { LBP or neck pain due to disc lesion and } \\
\text { radicular pain, spondylosis, spinal stenosis, } \\
\text { FBSS } \\
\text { Technique: } \\
\text { Drugs: local anesthetic + steroid } \\
\text { Imaging: fluoroscopy-guided commonly, } \\
\text { ultrasound may be used } \\
\text { Approach: interlaminar (common, safe), } \\
\text { transforaminal, or caudal } \\
\text { Cervical and lumbar epidural steroid injections } \\
\text { shown effective for short-term radicular pain } \\
\text { symptoms [118, 119] } \\
\text { Fair evidence for chronic thoracic pain and } \\
\text { limited for post thoracotomy pain [120] }\end{array}$ & $\begin{array}{l}\text { Failure, pain, IV injection, intrathecal } \\
\text { injection, headache, hypotension, infection } \\
\text { (rare), epidural hematoma (rare), vascular } \\
\text { spasm or injury with transforaminal } \\
\text { approach }\end{array}$ \\
\hline $\begin{array}{l}\text { Percutaneous } \\
\text { adhesiolysis }[121,122]\end{array}$ & $\begin{array}{l}\text { Lumbar post-surgery syndrome } \\
\text { (FBSS) } \\
\text { Approaches: caudal, interlaminar, or } \\
\text { transforaminal } \\
\text { Strong evidence for effectiveness in the } \\
\text { treatmentof chronic refractory low back and } \\
\text { lower extremity pain [122] }\end{array}$ & $\begin{array}{l}\text { Failure, pain, IV injection, intrathecal } \\
\text { injection, headache }\end{array}$ \\
\hline $\begin{array}{l}\text { Stellate ganglion block } \\
\qquad[123,124]\end{array}$ & $\begin{array}{l}\text { Sympathetic mediated pain of the upper limbs, } \\
\text { CRPS, phantom limb, acute herpes zoster } \\
\text { Injection by local anesthesia } \pm \text { steroids } \\
\text { Or, may be RF } \\
\text { Ultrasound- or fluoroscopy-guided } \\
\text { Strong evidence for use in CRPS, first-choice } \\
\text { interventional treatment for upper-extremity } \\
\text { CRPS [124] }\end{array}$ & $\begin{array}{l}\text { IV injection } \\
\text { Intrathecal injection } \\
\text { Hematoma } \\
\text { Pneumothorax } \\
\text { Recurrent laryngeal nerve block }\end{array}$ \\
\hline
\end{tabular}


Table 4 continued

\begin{tabular}{|c|c|c|}
\hline Pain procedure & Indications and technique & Drawbacks \\
\hline $\begin{array}{l}\text { Lumber sympathetic } \\
\text { block }[123,124]\end{array}$ & $\begin{array}{l}\text { Sympathetic mediated pain of the lower limbs } \\
\text { CRPS, phantom limb } \\
\text { Injection by local anesthetic } \pm \text { steroid } \\
\text { Or neurolytic ( } 5 \mathrm{ml} \text { of phenol } 6 \%) \\
\text { Fluoroscopy-guided } \\
\text { Strong evidence for use in CRPS, first-choice } \\
\text { interventional treatment for lower-extremity } \\
\text { CRPS [124] }\end{array}$ & $\begin{array}{l}\text { IV injection } \\
\text { Intrathecal or epidural injection } \\
\text { Somatic nerve neuralgia }\end{array}$ \\
\hline $\begin{array}{l}\text { Intradiscal biacuplasty } \\
\text { (IDB) }[100,125]\end{array}$ & $\begin{array}{l}\text { IDB may be considered for young active } \\
\text { patients with early single-level degenerative } \\
\text { disc disease with well-maintained disc height } \\
\text { Strong evidence for use in treatment of } \\
\text { chronic, refractory discogenic pain }[125]\end{array}$ & $\begin{array}{l}\text { Nerve damage } \\
\text { Disc damage } \\
\text { Disc infection }\end{array}$ \\
\hline $\begin{array}{l}\text { Spinal cord simulation } \\
\quad(\mathrm{SCS})[126-128]\end{array}$ & $\begin{array}{l}\text { CRPS (strong evidence) [127] } \\
\text { Ischemic pain (approved for use in Europe, } \\
\text { clinical efficacy seen in RCTs) [128] } \\
\text { Persistent radicular pain (strong evidence) } \\
\quad[127] \\
\text { Failed back surgery syndrome (strong evidence } \\
\text { for lumbar FBSS) [127] } \\
\text { PHN and phantom limb pain }\end{array}$ & $\begin{array}{l}\text { Accidental dural puncture and headache } \\
\text { Infection, trauma to neural structures, failure }\end{array}$ \\
\hline $\begin{array}{l}\text { Intraspinal implants (e.g., } \\
\text { epidural or spinal) } \\
{[129,130]}\end{array}$ & $\begin{array}{l}\text { Continuous drug delivery for long-term (e.g., } \\
\text { cancer) pain } \\
\text { Usually spinal opioids } \\
\text { Epidural and intraspinal analgesics both } \\
\text { equally effective [130] }\end{array}$ & $\begin{array}{l}\text { Infection, hematoma } \\
\text { Migration of the catheter } \\
\text { Neural trauma }\end{array}$ \\
\hline
\end{tabular}

patient's life such that comorbid conditions, lifestyle, patient preferences, and mental health are all taken into account. Conservative therapies such as weight loss, healthful eating, exercise, and relaxation techniques can be helpful along with assistive devices (such as braces or shoe orthotic inserts) along with psychological counseling and coping skills, but these approaches require a level of motivation and commitment on the part of the patient.

\section{ACKNOWLEDGEMENTS}

Funding. No funding or sponsorship was received for this study or publication of this article.

Medical Writing and Editorial Assistance. The authors would like to thank Rania S. Ahmed, College of Medical, Alfaisal University, Riyadh, Saudi Arabia, for assistance in medical 
writing and editing. No financial payment was made.

Authorship. All authors meet the International Committee of Medical Journal Editors (ICMJE) criteria for authorship for this article.

Disclosures. Dr. Pergolizzi discloses the following relationships: Consultant/Speaker and Researcher for BDSI, Salix, Nuerana, Enalare, Scilex, and Neumentum. I have no relationship with this specific research.

Dr. Christo reports consulting fees from Lilly and GSK, outside the submitted work; he has no other conflicts to disclose.

Dr. El-Tallawy, Dr. Nalamasu, Dr. Salem, and Ms. LeQuang have nothing to disclose.

Compliance with Ethics Guidelines. This article is based on previously conducted studies and does not contain any studies with human participants or animals performed by any of the authors.

Data Availability. Data sharing is not applicable to this article, as no datasets were generated or analyzed during the current study.

Open Access. This article is licensed under a Creative Commons Attribution-NonCommercial 4.0 International License, which permits any non-commercial use, sharing, adaptation, distribution and reproduction in any medium or format, as long as you give appropriate credit to the original author(s) and the source, provide a link to the Creative Commons licence, and indicate if changes were made. The images or other third party material in this article are included in the article's Creative Commons licence, unless indicated otherwise in a credit line to the material. If material is not included in the article's Creative Commons licence and your intended use is not permitted by statutory regulation or exceeds the permitted use, you will need to obtain permission directly from the copyright holder. To view a copy of this licence, visit http://creativecommons.org/licenses/by$\mathrm{nc} / 4.0 /$.

\section{REFERENCES}

1. Vos T, Abajobir AA, Abate KH, et al. Global, regional, and national incidence, prevalence, and years lived with disability for 328 diseases and injuries for 195 countries, 1990-2016: a systematic analysis for the Global Burden of Disease Study 2016. Lancet. 2017;390:1211-59.

2. WHO. Musculoskeletal Conditions. World Health Organization. https://www.who.int/news-room/ fact-sheets/detail/musculoskeletal-conditions. Published 2019. Accessed July 17, 2020.

3. Smith E, Hoy DG, Cross M, et al. The global burden of other musculoskeletal disorders: estimates from the Global Burden of Disease 2010 study. Ann Rheum Dis. 2014;73:1462-9.

4. Cimmino MA, Ferrone C, Cutolo M. Epidemiology of chronic musculoskeletal pain. Best Pract Res Clin Rheumatol. 2011;25:173-218.

5. Babatunde OO, Jordan JL, Windt DA, et al. Effective treatment options for musculoskeletal pain in primary care: a systematic overview of current evidence. PLoS ONE. 2017;12:e0178621.

6. Ernstzen DV, Louw QA, Hillier SL. Clinical practice guidelines for the management of chronic musculoskeletal pain in primary healthcare: a systematic review. Implement Sci. 2017;12:1.

7. Merskey H, Fessard D, Bonica JJ, et al. Pain terms: a list with definitions and notes on usage. Recommended by the IASP subcommittee on taxonomy. Pain. 1979;6:249-52.

8. Breivik H, Collett B, Ventafridda V, Cohen R, Gallacher D. Survey of chronic pain in Europe: prevalence, impact on daily life, and treatment. Eur J Pain. 2006;10(4):287-333.

9. Koechlin H, Whalley B, Welton NJ, Locher C. The best treatment option(s) for adult and elderly patients with chronic primary musculoskeletal pain: a protocol for a systematic review and network meta-analysis. Syst Rev. 2019;8:269. https://doi.org/ 10.1186/s13643-019-1174-6.

10. Bedson J, Mottram S, Thomas E, Peat G. Knee pain and osteoarthritis in the general population: what influences patients to consult? Fam Pract. 2007;24: 443-53.

11. James SL, Abate D, Abate KH, et al. Global, regional, and national incidence, prevalence, and years lived with disability for 354 diseases and injuries for 195 countries and territories, 1990-2017: a systematic analysis for the Global Burden of Disease Study 2017. Lancet. 2018;392:1789-858. 
12. Cimmino MA, Ferrone C, Cutolo M. Epidemiology of chronic musculoskeletal pain. Best Pract Res Clin Rheumatol. 2011;25(2):173-83.

13. Docking RE, Beasley M, Steinerowski A, Jones EA, Farmer J, Macfarlane GJ, Jones GT. The epidemiology of regional and widespread musculoskeletal pain in rural versus urban settings in those $\geq 55$ years. Br J Pain. 2015;9(2):86-95. https://doi.org/10. $1177 / 2049463714527438$.

14. Lewis R, Álvarez CBG, Rayman M, Lanham-New S, Woolf A, Mobasheri A. Strategies for optimising musculoskeletal health in the 21st century. BMC Musculoskelet Disord. 2019;20(1):164. https://doi. org/10.1186/s12891-019-2510-7.

15. Gransjøen AM, Lysdahl KB, Hofmann BM. Geographical variations in the use of diagnostic imaging of musculoskeletal diseases in Norway. Acta Radiol. 2018;60(9):1153-8. https://doi.org/10.1177/ 0284185118812204.

16. Brekke M, Hjortdahl P, Kvien TK. Severity of musculoskeletal pain: relations to socioeconomic inequality. Soc Sci Med. 2002;54(2):221-8. https:// doi.org/10.1016/s0277-9536(01)00018-1.

17. Raja SN, Carrb DB, Cohenc M, et al. The revised International Association for the Study of Pain definition of pain: concepts, challenges, and compromises. Pain. 2020. https://journals.lww.com/ pain/toc/9000/00000.

18. Koechlin H, Whalley B, Welton NJ, Locher C. The best treatment option(s) for adult and elderly patients with chronic primary musculoskeletal pain: a protocol for a systematic review and metaanalysis. Syst Rev. 2019;8:269. https://doi.org/10. 1186/s13643-019-1174-6.

19. Lin I, Wiles L, Waller R, Goucke R, Nagree Y, Gibberd M, Straker L, Maher C, O'Sulliva P. What does best practice care for musculoskeletal pain look like? Eleven consistent recommendations from highquality clinical practice guidelines: systematic review. Br J Sports Med. 2020;54:79-86.

20. Ivanova JI, Birnbaum HG, Schiller M, et al. Realworld practice patterns, health-care utilization, and costs in patients with low back pain: the long road to guideline-concordant care. Spine J. 2011;11: 622-32.

21. Cho NH, Jung YO, Lim SH, Chung CK, Kim HA. The prevalence and risk factors of low back pain in rural community residents of Korea. Spine. 2012;37: 2001-10.

22. Evidence-based clinical guidelines for multidisciplinary spine care: diagnosis and treatment of low back pain. 2020; North American Spine Society. https://www.researchgate.net/publication/ 338925112.

23. Abdel Shaheed C, Maher CG, Williams KA, et al. Efficacy, tolerability, and dose- dependent effects of opioid analgesics for low back pain: a systematic review and meta- analysis. JAMA Intern Med. 2016;176:958.

24. Manchikanti L, Kaye AM, Knezevic NN, et al. Responsible, safe, and effective prescription of opioids for chronic non-cancer pain: American Society of Interventional Pain Physicians (ASIPP) Guidelines. Pain Physician. 2017;20:S3-S92. ISSN 1533-3159.

25. Christo PJ. Opioids may be appropriate for chronic pain. J Law Med Ethics. 2020;48(2):241-8. https:// doi.org/10.1177/1073110520935335.

26. Adelani MA, Harris AH, Bowe TR, et al. Arthroscopy for knee osteoarthritis has not decreased after a clinical trial. Clin Orthop Relat Res. 2016;474:489.

27. Ketola S, Lehtinen JT, Arnala I. Arthroscopic decompression not recommended in the treatment of rotator cuff tendinopathy: a final review of a randomised controlled trial at a minimum followup of ten years. Bone Joint J. 2017;99-B:799-805.

28. Beard DJ, Rees JL, Cook JA, et al. Arthroscopic subacromial decompression for subacromial shoulder pain (CSAW): a multicentre, pragmatic, parallel group, placebo-controlled, three-group, randomised surgical trial. Lancet. 2018;391:329-38. https://doi. org/10.1016/S0140-6736(17)32457-1.

29. El-Tallawy SN, Nalamasu R, Pergolizzi JV, Gharibo C. Pain management during the COVID-19 pandemic. Pain Ther. 2020;9:453-66. https://doi.org/ 10.1007/s40122-020-00190-4.

30. Russell IJ. Future perspectives in generalised musculoskeletal pain syndromes. Best Pract Res Clin Rheumatol. 2011;25(2):321-31.

31. Dieppe P. Chronic musculoskeletal pain. BMJ (Clin Res Ed). 2013;346:f3146.

32. Cox F. Basic principles of pain management: assessment and intervention. Nurs Stand. 2010;25(1):36-9.

33. Treede R-D, Rief W, Barke A, et al. Chronic pain as a symptom or a disease: the IASP Classification of Chronic Pain for the International Classification of Diseases (ICD-11). Pain. 2019;160(1):19-27. https:// doi.org/10.1097/j.pain.0000000000001384.

34. Sinatra R. Pain pathways and pain processing. In: Sinatra RS, de Leon-Cassasola O, Ginsberg B, Viscusi 
G, editors. Acute pain management. Cambridge: Cambridge University Press; 2009. p. 3-21.

35. Stucky C. Mechanisms of pain. PNAS. 2001;98: 11845-6.

36. Schug SA, Palmer GM, Scott DA, Halliwell R, Trinca J. Acute pain management: scientific evidence fourth edition, 2015. Med J Aust. 2016;204(8): 315-7.

37. D'Mello R, Dickenson AH. Spinal cord mechanisms of pain. Br J Anaesth. 2008;101(1):8-16.

38. Bates D, Schultheis DC, Hanes MC, Jolly SM, Chakravarthy KV, Deer TR, Levy RM, Hunter CW. A Comprehensive algorithm for management of neuropathic pain. Pain Med. 2019;20:S2-12.

39. IASP Terminology. International Association for the Study of Pain. Education Web site. https://www. iasp-pain.org/Education/Content. aspx?ItemNumber=1698. Published 2020. Accessed September 10, 2020.

40. Scottish Intercollegiate Guidelines Network (SIGN). Management of chronic pain. Edinburgh: SIGN; 2013, Revised 2019. (SIGN publication no. 136). https://www.sign.ac.uk/assets/sign136.pdf.

41. Rosenquist RW, Benzon HT, Connis RT, et al. Practice guidelines for chronic pain management: an updated report by the American Society of Anesthesiologists Task Force on Chronic Pain Management and the American Society of Regional Anesthesia and Pain Medicine. Anesthesiology. 2010;112:1-1.

42. Turk DC, Dworkin RH, Allen RR, et al. Core outcome domains for chronic pain clinical trials: IMMPACT recommendations. Pain. 2003;106(3): 337-45. https://doi.org/10.1016/j.pain.2003.08. 001.

43. Rawal N. Current issues in postoperative pain management. Eur J Anaesthesiol. 2016;33:160-71.

44. Chou R, Gordon DB, de Leon-Casasola OA, et al. Guidelines on the management of postoperative pain: a clinical practice guideline from the American Pain Society, the American Society of Regional Anesthesia and Pain Medicine, and the American Society of Anesthesiologists. J Pain. 2016;17(2): 131-57.

45. Bennett MI, Attal N, Backonja MM, Baron R, Bouhassira D, Freynhagen R, Scholz J, Tolle TR, Wittchen HU, Staehelin T. Using screening tools to identify neuropathic pain. Pain. 2007;127:199-203.

46. Qaseem A, Wilt TJ, McLean RM, Forciea MA. Noninvasive treatments for acute, subacute, and chronic low back pain: a clinical practice guideline from the American College of Physicians. Ann Intern Med. 2017;166:514-30. https://doi.org/10.7326/M162367.

47. Gatchel RJ, McGeary DD, McGeary CA, Lippe B. Interdisciplinary chronic pain management: past, present, and future. Am Psychol. 2014;69(2): 119-30. https://doi.org/10.1037/a0035514.

48. Gatchel RJ, Peng YB, Peters ML, Fuchs PN, Turk DC. The biopsychosocial approach to chronic pain: scientific advances and future directions. Psychol Bull. 2007;133(4):581-624. https://doi.org/10.1037/ 00332909.133.4.581.

49. Loeser JD. Multidisciplinary pain programs. In: Loeser JD, editor. Bonica's management of pain. 3rd ed. Philadelphia: Lippincott, Williams \& Wilkins; 2001. p. 255-64.

50. DeLisa JA. Treatment of the patient with chronic pain. In: DeLisa's physical medicine \& rehabilitation. Principles and practice. 5th ed. Philadelphia: Lippincott, Williams \& Wilkins; 2010. p. 1273-318.

51. King JC, Kelleher WJ. The chronic pain syndrome: the in-patient interdisciplinary rehabilitative behavioral modification approach. Phys Med Rehabil Stars. 1991;5:165-86.

52. Christo PJ, Mazloomdoost D. Cancer pain and analgesia. Ann N Y Acad Sci. 2008;1138:278-98.

53. Yang J, Bauer BA, WahnerRoedler DL, Chon TY, Xiao L. The modified WHO analgesic ladder: is it appropriate for chronic non-cancer pain? J Pain Res. 2020;13:411-7.

54. Graham GG, Davies MJ, Day RO, et al. The modern pharmacology of paracetamol: therapeutic actions, mechanism of action, metabolism, toxicity and recent pharmacological findings. Inflammopharmacology. 2013;21(3):201-32.

55. Da Costa BR, Reichenbach S, Keller N, Nartey L, Wandel S, Juni P, et al. Effectiveness of non- steroidal anti- inflammatory drugs for the treatment of pain in knee and hip osteoarthritis: a network metaanalysis. Lancet. 2017;390:e21-33.

56. Kolasinski SL, Neogi T, Hochberg MC, et al. 2019 American College of Rheumatology/Arthritis Foundation guideline for the management of osteoarthritis of the hand, hip, and knee. Arthritis Care Res. 2020;72(2):149-62. https://doi.org/10. $1002 /$ acr. 24131.

57. Lim YJ, Chun HJ. Recent advances in NSAIDs-induced enteropathy therapeutics: new options, new challenges. Gastroenterol Res Pract. 2013. https:// doi.org/10.1155/2013/761060. 
58. Derry S, Massey T, Moore RA, McQuay HJ. Topical NSAIDS for chronic musculoskeletal pain in adults. Cochrane Database Syst Rev. 2012;9(9):CD007400. https://doi.org/10.1002/14651858.CD007400.pub2.

59. Vallejo R, Barkin RL, Wang VC. Pharmacology of opioids in the treatment of chronic pain syndromes. Pain Physician. 2011;14(4):E343-60.

60. Baldini A, Von Korff M, Lin EH. A review of potential adverse effects of long-term opioid therapy: a practitioner's guide. Prim Care Companion CNS Disord. 2012. https://doi.org/10.4088/PCC. $11 \mathrm{~m} 01326$ (Epub 2012 Jun 14).

61. Kroenke K, Alford DP, Argoff C, et al. Challenges with implementing the Centers for Disease Control and Prevention Opioid Guideline: a consensus panel report. Pain Med. 2019;20(4):724-35. https:// doi.org/10.1093/pm/pny307.

62. Phillips JK, Ford MA, Bonnie RJ. Pain management and the opioid epidemic: balancing societal and individual benefits and risks of prescription opioid use. National Academies of Sciences. National Academies Press (US); 2017. ISBN-13: 978-0-309-459549, ISBN-10: 0-309-45954-0.

63. Chou R, Turner JA, Devine EB, Hansen RN, Sullivan $\mathrm{SD}$, Blazina I, et al. The effectiveness and risks of long-term opioid therapy for chronic pain: a systematic review for a National Institutes of Health Pathways to Prevention Workshop. Ann Intern Med. 2015;162(4):276-86.

64. Vowles KE, McEntee ML, Julnes PS, Frohe T, Ney JP, van der Goes DN. Rates of opioid misuse, abuse, and addiction in chronic pain: a systematic review and data synthesis. Pain. 2015;156(4):569-76.

65. Hepner S, Claxton R. Anti-epileptic drugs for pain. J Palliat Med. 2013;16(7):799-800.

66. Wright ME. An update on the pharmacologic management and treatment of neuropathic pain. J Am Acad Physician Assist. 2017;30(3):13-7.

67. Urquhart DM, Wluka AE, van Tulder M, et al. Efficacy of low-dose amitriptyline for chronic low back pain: a randomized clinical trial. JAMA Intern Med. 2018;178(11):1474-81. https://doi.org/10.1001/ jamainternmed2018.4222.

68. Annemans L. Pharmacoeconomic impact of adverse events of long-term opioid treatment for the management of persistent pain. Clin Drug Investig. 2011;31(2):73-86.

69. Takkouche B, Montes-Martinez A, Gill SS, Etminan M. Psychotropic medications and the risk of fracture: a meta-analysis. Drug Saf. 2007;30(2):171-84.
70. Cheatle MD, Shmuts R. The risk and benefit of benzodiazepine use in patients with chronic pain. Pain Med. 2015;16(2):219-21. https://doi.org/10. 1111/pme.12674.

71. Giovannitti JA, Thoms SM, Crawford JJ. Alpha-2 adrenergic receptor agonists: a review of current clinical applications. Anesth Prog. 2015;62(1):31-9. https://doi.org/10.2344/0003-3006-62.1.31.

72. Chaparro LE, Wiffen PJ, Moore RA, Gilron I. Combination pharmacotherapy for the treatment of neuropathic pain in adults. Cochrane Database Syst Rev. 2012;7:CD008943. https://doi.org/10.1002/ 14651858.CD008943.pub2.

73. Plested M, Budhia S, Gabriel Z. Pregabalin, the lidocaine plaster and duloxetine in patients with refractory neuropathic pain: a systematic review. BMC Neurol. 2010;10:116.

74. Derry S, Moore RA. Topical capsaicin (low concentration) for chronic neuropathic pain in adults. Cochrane Database Syst Rev. 2012;9:CD010111. https://doi.org/10.1002/14651858.CD010111.

75. Hicks CW, Selvin E. Epidemiology of peripheral neuropathy and lower extremity disease in diabetes. Current Diabetes Rep. 2019;19(10):86. https://www. ncbi.nlm.nih.gov/pmc/articles/PMC6755905/\#!po= 48.3333. Accessed July 6, 2020.

76. Chahla J, Mannava S, Cinque ME, Geeslin AG, Codina D, LaPrade RF. Bone marrow aspirate concentrate harvesting and processing technique. Arthrosc Tech. 2017;6(2):e441-5. https://doi.org/ 10.1016/j.eats.2016.10.024.

77. Manchikanti L, Centeno CJ, Atluri S, et al. Bone marrow concentrate (BMC) therapy in musculoskeletal disorders: evidence-based policy position statement of American Society of Interventional Pain Physicians (ASIPP). Pain Physician. 2020;23: E85-E131. ISSN 2150-1149.

78. Raff M, Belbachir A, El-Tallawy S, Ho KY, Nagtalon E, Salti A, Seo JH, Tantri AR, Wang H, Wang T, Buemio KC, Gutierrez C, Hadjiat Y. Intravenous oxycodone versus other intravenous strong opioids for acute postoperative pain control: a systematic review of randomized controlled trials. Pain Ther. 2019;8(1):19-39.

79. Pergolizzi JV, Raffa RB. Safety and efficacy of the unique opioid buprenorphine for the treatment of chronic pain. J Pain Res. 2019;12:3299-317.

80. Beal BR, Wallace MS. An overview of pharmacologic management of chronic pain. Med Clin N Am. 2016;100(1):65-79. 
81. Kaye AD, Cornett EM, Hart B, et al. Novel pharmacological nonopioid therapies in chronic pain. Curr Pain Headache Rep. 2018;22(4):31.

82. vanTulder MW, Koes BW, Bouter LM. Conservative treatment of acute and chronic non-specific low back pain: a systematic review of randomized control trials of the most common interventions. Spine. 1997;22:2128-56.

83. Abenhaim L, Rossignol M, Valat JP, et al. The role of activity in therapeutic management of back pain: report of the international Paris task force on back pain. Spine. 2000;25:1S-33S.

84. Qaseem A, Wilt TJ, McLean RM, et al. Noninvasive treatments for acute, subacute, and chronic low back pain: a clinical practice guideline from the American College of Physicians. Ann Intern Med. 2017;166:514.

85. Swenson C, Sward L, Karlsson J. Cryotherapy in sports medicine. Scand J Med Sci Sports. 1996;6(4): 193-200.

86. Gooch JL, Geiringer SR, Akau CK. Sports medicine. 3. Lower extremity injuries. Arch Phys Med Rehabil. 1993;74:S438-42.

87. Fischer E, Solomon S. Physiological responses to heat and cold. In: Licht S, editor. Therapeutic heat and cold. 2nd ed. Baltimore: Waverly; 1965. p. 126-69.

88. Kottke FJ, Pauley DL, Rudolph PA. The rational for prolonged stretching for correction of shortening of connective tissue. Arch Phys Med Rehabil. 1966;47: $345-52$.

89. French SD, Cameron M, Walker BF, et al. Superficial heat or cold for low back pain. Cochrane Database Syst Rev. 2006;1:CD004750. https://doi.org/10. 1002/14651858.CD004750.pub2.

90. Melzack R, Wall PD. Pain mechanisms: a new theory. Science. 1965;150:971-7.

91. Canthen JC, Renner EJ. Transcutaneous and peripheral nerve for chronic pain states. Surg Neural. $1975 ; 11: 102-4$.

92. Meyer GA, Fields HL. Causalgia treated by selective large fiber stimulation of peripheral nerve. Brain. 1972;95:163-8.

93. Hansson P, Lundeberg T. Transcutaneous electrical nerve stimulation and acupuncture. In: McMahon SB, Koltzenburg M, editors. Wall and Melzack's textbook of pain. 5th ed. Philadelphia: Elsevier Churchill Livingstone; 2006. p. 583-90.
94. Vance CGT, Dailey DL, Rakel BA, Sluka KA. Using TENS for pain control: the state of the evidence. Pain Manag. 2014;4(3):197-209. https://doi.org/10. 2217/pmt.14.13.

95. Trinh KV, Graham N, Gross AR, Cervical Overview Group, et al. Acupuncture for neck disorders. Cochrane Database Syst Rev. 2006;3:CD004870. https://doi.org/10.1002/14651858.CD004870.pub3.

96. Furlan AD, van Tulder MW, Cherkin DC, Tsukayama H, Lao L, Koes BW, Berman BM. Acupuncture and dry-needling for low back pain. Cochrane Database Syst Rev. 2005;1:CD001351. https://doi. org/10.1002/14651858.CD001351.pub2.

97. Wu WH, Akande AA. Alternative medicine for chronic pain: a critical review. In: Aronoff GM, editor. Evaluation and treatment in chronic pain. 3rd ed. Baltimore: Williams \& Wilkins; 1998. p. 627-41.

98. Mannion AF, Taimela S, Muntener M, et al. Active therapy for chronic low back pain, part I: effects on back muscle activation, fatigability, and strength. Spine. 2001;26(8):897-908.

99. Kim LH, Vail D, Azad TD, et al. Expenditures and health care utilization among adults with newly diagnosed low back and lower extremity pain. JAMA Netw Open. 2019;2(5):e193676. https://doi. org/10.1001/jamanetworkopen.2019.3676.

100. Peter WF, Jansen MJ, Hurkmans EJ, et al. Physiotherapy in hip and knee osteoarthritis: development of a practice guideline concerning initial assessment, treatment and evaluation. Acta Reumatol Port. 2011;36:268-81.

101. Bussières AE, Stewart G, Al- Zoubi F, et al. The treatment of neck pain- associated disorders and whiplash-associated disorders: a clinical practice guideline. J Manipulative Physiol Ther. 2016;39: 523-64.

102. National Institute for Health and Clinical Excellence (NICE). Osteoarthritis: care and management (CG177). London: National Institute for Health and Clinical Excellence; 2014. https://www.nice.org.uk/ guidance/cg177.

103. National Institute for Health and Clinical Excellence (NICE). Low back pain and sciatica in over 16s: assessment and management (NG59). London: National Institute for Health and Clinical Excellence, NICE guideline Published: 30 November 2016 http://www.nice.org.uk/guidance/ng59.

104. Wiegel M, Gottschaldt U, Hennebach R, Hirschberg $\mathrm{T}$, Reske A. Complications and adverse effects associated with continuous peripheral blocks in 
orthopedic patients. Anesth Analg. 2007;104(1): 1578-82.

105. Chelly JE, Ghisi D, Fanelli A. Continuous peripheral nerve blocks in acute pain management. $\mathrm{Br} \mathrm{J}$ Anaesth. 2010;105(1):i86-96.

106. Borg-Stein J, Iaccarino MA. Myofascial pain syndrome treatments. Phys Med Rehabil Clin N Am. 2014;25(2):357-74.

107. Wong CS, Wong SH. A new look at trigger point injections. Anesthesiol Res Pract. 2012;2012: 492452. https://doi.org/10.1155/2012/492452.

108. Park CJ, Shin YD, Lim SW, Bae YM. The effect of facet joint injection on lumbar spinal stenosis with radiculopathy. Pak J Med Sci. 2018;34(4):968-73.

109. Manchikanti L, Kaye AD, Soin A, et al. Comprehensive evidence-based guidelines for facet joint interventions in the management of chronic spinal pain: American Society of Interventional Pain Physicians (ASIPP) guidelines. Pain Physician. 2020;23:S1-S127. ISSN 2150-1149.

110. Boswell MV, Manchikanti L, Kaye AD, Bakshi S, Gharibo CG, Gupta S, Jha SS, Nampiaparampil DE, Simopoulos TT, Hirsch JA. A best-evidence systematic appraisal of the diagnostic accuracy and utility of facet (zygapophysial) joint injections in chronic spinal pain. Pain Physician. 2015;18(4):E497-533.

111. Roberts SL, Burnham RS, Ravichandiran K, Agur AM, Loh EY. Cadaveric study of sacroiliac joint innervation: implications for diagnostic blocks and radiofrequency ablation. Reg Anesth Pain Med. 2014;39(6):456-64.

112. Zheng P, Schneider BJ, Yang A, McCormick ZL. Image-guided sacroiliac joint injections: an evidence-based review of best practices and clinical outcomes. J Inj Funct Rehabil. 2019;11:S98-104. https://doi.org/10.1002/pmrj.12191.

113. Curatolo M. Regional anesthesia in pain management. Curr Opin Anaesthesiol. 2016;29(5):614-9.

114. Chang A, Ly N, Varacallo M. Piriformis Injection. 2020 Sep 4. In: StatPearls [Internet]. Treasure Island: StatPearls Publishing; 2020. https://www.ncbi.nlm. nih.gov/books/NBK448193/.

115. Lee JH, Kim DH, Kim DH, et al. Comparison of clinical efficacy of epidural injection with or without steroid in lumbosacral disc herniation: a systematic review and meta-analysis. Pain Physician. 2018;21(5):449468.

116. Gharibo C, Koo C, Chung J, Moroz A. Epidural steroid injections: an update on mechanisms of injury and safety. Tech Reg Anesth Pain Manag. 2009;13:266-71.

117. House LM, Barrette K, Mattie R, McCormick ZL. Cervical epidural steroid injection: techniques and evidence. Phys Med Rehabil Clin N Am. 2018;29(1): 1-17. https://doi.org/10.1016/j.pmr.2017.08.001 (Epub 2017 Oct 16).

118. Rivera CE. Lumbar epidural steroid injections. Phys Med Rehabil Clin N Am. 2018;29(1):73-92. https:// doi.org/10.1016/j.pmr.2017.08.007.

119. Benyamin RM, Wang VC, Vallejo R, Singh V, Helm IS. A systematic evaluation of thoracic interlaminar epidural injections. Pain Physician. 2012;15(4): E497-514.

120. Manchikanti L, Manchikanti KN, Gharibo C, Kaye AD. Efficacy of percutaneous adhesiolysis in the treatment of lumbar post surgery syndrome. Anesth Pain Med. 2016;6(2):e26172.

121. Helm S, Racz GB, Gerdesmeyer L, Justiz R, Hayek SM, Kaplan ED, El Terany MA, Knezevic NN. Percutaneous and endoscopic adhesiolysis in managing low back and lower extremity pain: a systematic review and meta-analysis. Pain Physician. 2016;19(2):E245-82.

122. Zhu X, Kohan LR, Morris JD, et al. Sympathetic blocks for complex regional pain syndrome: a survey of pain physicians. Reg Anesth Pain Med. 2019. https://doi.org/10.1136/rapm-2019-100418.

123. van Eijs F, Stanton-Hicks M, Van Zundert J, Faber CG, Lubenow TR, Mekhail N, van Kleef M, Huygen F. Evidence-based interventional pain medicine according to clinical diagnoses. 16. Complex regional pain syndrome. Pain Pract. 2011;11(1): 70-87. https://doi.org/10.1111/j.1533-2500.2010. 00388.x (Epub 2010 Aug 27).

124. Helm Ii S, Simopoulos TT, Stojanovic M, Abdi S, El Terany MA. Effectiveness of thermal annular procedures in treating discogenic low back pain. Pain Physician. 2017;20(6):447-70.

125. Verrills P, Sinclair C, Barnard A. A review of spinal cord stimulation systems for chronic pain. J Pain Res. 2016;9:481-92.

126. Deer TR, Grider JS, Lamer TJ, Pope JE, et al. A systematic literature review of spine neurostimulation therapies for the treatment of pain. Pain Med. 2020;21(7):1421-32. https://doi.org/10.1093/pm/ pnz353.

127. Song JJ, Popescu A, Bell RL. Present and potential use of spinal cord stimulation to control chronic pain. Pain Physician. 2014;17(3):235-46. 
128. Grider JS, Manchikanti L, Carayannopoulos A, Sharma ML, Balog CC, Harned ME, Grami V, Justiz R, Nouri KH, Hayek SM, Vallejo R, Christo PJ. Effectiveness of spinal cord stimulation in chronic spinal pain: a systematic review. Pain Physician. 2016;19(1):E33-54.

129. Hayek SM, Deer TR, Pope JE, Panchal SJ, Patel VB. Intrathecal therapy for cancer and non-cancer pain. Pain Physician. 2011;14(3):219-48.
130. Kongsgaard U, Kaasa S, Dale O, Ottesen S, Nordøy T, Hessling SE, von Hofacker S, Bruland ØS, Lyngstadaas A. Palliative treatment of cancer-related pain [Internet]. Oslo: Knowledge Centre for the Health Services at The Norwegian Institute of Public Health (NIPH); 2005. Report from Norwegian Knowledge Centre for the Health Services (NOKC) No. 09-2005. 